\title{
Anne MacDonald
}

\section{Interpreting Prasannapadā 19.3-7 in Context A Response to Claus Oetke*}

In the preceding article of this same volume of the Wiener Zeitschrift für die Kunde Südasiens (WZKS), Claus Oetke examines a short but challenging passage from the first chapter of Candrakinti's Prasannapadā (henceforth PsP) for which I, in a WZKS 2000 article entitled "The Prasannapadā: More Manuscripts from Nepal," presented textual emendations and a translation based on the emended text. ${ }^{1}$ As indicated by the title of Oetke's, and now my own, article, the passage involved is found in de La Vallée Poussin's edition of the PsP (henceforth $\mathrm{PsP}_{\mathrm{L}}$ ) on page 19, lines 3-7. Oetke accepts, with one exception, the emendations I make to the text of the passage, but criticizes and rejects my interpretation of it. He offers an alternative interpretation of the passage - embodied in his own translation of the emended version of $\mathrm{PsP}_{\mathrm{L}}$ 19.3-7 and underpinned with context-specific analysis - that he considers to be preferable to mine because it has, in his opinion, been derived in reliance on more methodologically solid principles than those he considers I used. His superior methodological approach, he believes, enables his interpretation "to account for all details." ${ }^{2}$ He claims that in my approach to the material certain traits can be discerned that "are suited to hamper progress." He specifies: "One trait which can be detected even in 'good philological tradition,' but which impedes a more efficient employment of methodological tools, is a particular type of lack of self-reflection." This lack of self-reflection, he explains, "con-

* I am indebted to Prof. Lambert Schmithausen and Prof. Karin Preisendanz for their insightful comments on the text passages discussed here and for their suggestions regarding the present paper. I am also grateful to Dr. Birgit Kellner for reading the paper and for her most helpful remarks.

1 Cf. MacDonald 2000: 174-179.

2 Oetke elaborates his statement that one should account for all details in textual interpretation in the maxim: "If one entertains the hypothesis that some expression $\mathrm{E}$ means (that) $\mathrm{P}$ - or: that the producer of $\mathrm{E}$ has meant by $\mathrm{E}$ that $\mathrm{P}$ - one should consider all expressions occurring in the same (con)text as E, including all meaning-constitutive elements of $\mathrm{E}$, and ask which function could be ascribed to them if the hypothesis should be correct" (Oetke 2003: 131). 
sists in a tendency to rely on intuitions at the expense of explicit and rigorous investigations on objective properties which an interpretation that one has proposed or wants to propose possess" (Oetke 2003: 130).

It is not my intention to restate here Oetke's rather prolix explanation of the principles he advocates and thinks he utilized to reach his interpretation of the emended $\mathrm{PsP}_{\mathrm{L}}$ 19.3-7 passage, and I refer the interested reader to the latter part of his article for it. In brief, he primarily discusses two principles, termed by him the "principle of optimal linguistic performance" and the "principle of optimal contextual relevance," respectively, collectively "optimality-principles of interpretation," which have been obtained in large part in reliance on P. Grice's conversational maxims. These principles become relevant in cases where more than one interpretation offers itself for a given interpretandum in that they provide criteria for evaluating competing interpretations and for distinguishing the most appropriate among them. The first assumes that the interpretation of a statement which best achieves the goals of the author, i.e., the interpretation whose entailed goals are more optimally realized by the interpretandum than the other goals entailed by other interpretations, is to be opted for, and that this interpretation should be the one that most satisfactorily accounts for all of the statement's elements. This principle presupposes that an author who is aiming to convey a message will attempt to formulate it in a way conducive to getting this message across. The second principle recognizes as relevant to the understanding of a statement the assessment of sentences within the larger context of the unit to be interpreted because these are commonly designed, along with the interpretandum, to contribute to the realization of a common goal. Now, Oetke admits that these principles have been implicitly acknowledged in the Sanskrit philological tradition. ${ }^{3}$ His contention is that they are being increasingly disregarded, to the extent that Sanskrit philology's very right to exist is threatened.

While I tend to disagree with Oetke's generally extreme views regarding the state of Indology, I fully concur with his judgement regarding the value of and need for the exploitation of specific, effective methodologies in textual interpretation. The, in my opinion, fairly self-evident principles he is exhorting philologists to avail themselves of are indeed serviceable and effective aids in any attempt to discern an author's

3 Oetke 2003: 138. 
message and the meaning of the words and sentences that convey that message. The majority of scholars who have been trained in the Frauwallnerian tradition of textual interpretation, among whom I count myself, apply such - even if they do not term them as Oetke does - and similar principles in their work. But they are also aware that there are other factors crucial for the correct interpretation of texts. Oetke himself, but only in passing, remarks that "optimality-principles do not exhaust everything that is relevant for assessments of interpretations." In addition to the use of, as Oetke describes it, criteria derived from maxims of everyday speech, successful interpretation also requires awareness of the conventions of specialized, technical discourse, i.e., of the discussions between Indian philosophers, and knowledge of the idiomatic of the language, i.e., knowledge of language use. It is unfortunate that Oetke limited his approach to the material as he did because it has led to errors in his translation and interpretation of $\mathrm{PsP}_{\mathrm{L}}$ 19.3-7. Readers will make their own judgements, but it also seems that Oetke has failed to successfully apply the very methodology he preaches.

I became aware of the "new and improved" interpretation of the emended version of $\mathrm{PsP}_{\mathrm{L}}$ 19.3-7 during a brief email discussion with Oetke concerning particulars of the passage in the autumn of 1999, shortly after I had presented my emendations for the passage in a paper read at the Twelfth Conference of the International Association of Buddhist Studies. Oetke initially disagreed that $\mathrm{PsP}_{\mathrm{L}} 19.3$ should be emended from na cāyam to sa cāyam, but then came to prefer my emendation. His further deliberations at that time gave rise to the basic views now expressed in his article, in brief, that the person referred to by the pronoun ayam in sa cāyam must be a Mādhyamika, and not the Sānkhya opponent, as I assume him to be. Much as I appreciated Oetke's engagement with the passage, I found his interpretation to be so unacceptable that I decided against even mentioning it as straw man in my WZKS 2000 article. The remarks that I did make in regard to the possibility of the referent of the pronoun ayam being the Mādhyamika were made with reference to the $\mathrm{PsP}_{\mathrm{L}} 19.3$ reading na cāyam and with Stcherbatsky's translation in mind. ${ }^{5}$ While I remain convinced of the utter unac-

4 Oetke 2003: 138.

5 Cf. Stcherbatsky's translation in MacDonald 2000: 175-176. For his recent translation of the same passage, C.W. Huntington relies, for reasons unstated, on Vaidya's edition of the PsP and accepts the reading na cāyam (see Huntington 2003: 89, n. 57). Following Stcherbatsky, he takes the main subject of the passage 
ceptability of Oetke's interpretation, I do welcome the opportunity to present my translation again, this time in an "updated" version with certain refinements, and to explicate the reasons for my interpretation. I find it almost superfluous to add that it will quickly become clear that my interpretation of the passage is by no means based on the intuitive "if it feels good, translate it that way" pseudo-methodology that Oetke accuses me of.

Since Oetke, in addition to presenting the emended text for $\operatorname{PsP}_{\mathrm{L}}$ 19.37 , includes de La Vallée Poussin's text for and a translation ${ }^{6}$ of the related section leading up to $\mathrm{PsP}_{\mathrm{L}}$ 19.3, i.e., from $\mathrm{PsP}_{\mathrm{L}} 14.1$ on, at the beginning of his article for the sake of providing the context for the main passage of interest, it may be appropriate and expedient to present here the revised text for this section, i.e., the text from my Sanskrit edition of the first chapter of the PsP, and my own translation of the segments of this section. ${ }^{7}$ Following Oetke, I omit the quotations at $\mathrm{PsP}_{\mathrm{L}}$ 16.4-10. My understanding of Candrakīrti's statements in this related section should become clearer therewith, and interested readers will have access to certain philological details and musings. Even though many of the textual changes or points of translation on which I take issue with Oetke and other translators in these earlier segments do not directly bear on the interpretation of the emended $\mathrm{PsP}_{\mathrm{L}}$ 19.3-7 segment, they are often important for the respective segments and therefore worthy of note. The interpretation of the $\mathrm{PsP}_{\mathrm{L}}$ 18.5-9 segment, on the other hand, plays a large role in Oetke's decision to interpret 19.37 as he does, and with it we completely part ways.

With the exception of my remarks on the significant emendations made to the $\mathrm{PsP}_{\mathrm{L}}$ 16.11-18.4 segment, I have tried to limit most of my com-

to be the Mādhyamika. He translates na cāyam as "This is not so [for a Mādhyamika]," therewith ignoring $c a$ and smuggling in the translation for a non-existent evam. He also ignores Vaidya's danda after param prati and construes param prati with the following sentence, translating param prati hetudrștāntāsambhavāt as "When he addresses someone else there is no possibility of resorting to any reason or example [of his own], so ..." (see Huntington 2003: 78f.).

${ }^{6}$ Oetke introduces his English rendering of the section with the words "... one can describe the train of thoughts of that passage as follows" (Oetke 2003: 114). He does not explain why he prefers (if he indeed does prefer) to view it as a "description." I refer to his English rendering as a "translation" because he attempts to reflect all of the section's linguistic details in it and because he employs in it the conventions, i.e., round and square brackets, of formal translation.

7 The Sanskrit and Tibetan editions and the translation are being prepared for publication. 
ments on the various textual problems to the notes. Discussions that had become unwieldly as notes have been included in an Appendix. Expressions in the Sanskrit text that are not supported by the available manuscripts of the PsP but that have been taken over from $\mathrm{PsP}_{\mathrm{L}}$ appear in Roman print. Emendations that are supported by the manuscripts appear in bold italics. Emendations neither supported by the manuscripts nor suggested by de La Vallée Poussin (LVP) are in bold Roman.

The relevant section occurs towards the beginning of the first chapter of the Prasannapadā, subsequent to Candrakīrti's remarks on the mangalaślokas of the Mūlamadhyamakakārikā (MMK) - a third of which he has devoted to criticizing Bhāviveka's comments on the etymology of the word pratītyasamutpāda - and his citation of MMK $1.1^{8}$ and brief comments on its individual words. Taking up the first position negated in MMK 1.1, namely, arising from self, a view that he attributes to the Sāṅkhya school, Candrakīrti cites Madhyamakāvatāra 6.8cd (tasmād dhi tasya bhavane na guno 'sti kaścij jātasya janma punar eva ca naiva yuktam //) as a reasoning demonstrating that arising from self is impossible (ef. $\mathrm{PsP}_{\mathrm{L}}$ 13.6: yaȳ copapattyā svata utpādo na sambhavati sā ... ). Following this citation, which is obviously based on the first ground in the statement of [unwanted] consequence ${ }^{9}$ (prasangavākya) Buddhapālita has set forth to elucidate the inacceptability of arising from self in his own commentary to MMK 1.1, Candrakīrti directly cites Buddhapālita's statement of unwanted consequence and its explanatory sentences.

$\mathrm{PsP}_{\mathrm{M}}$ (cp. $\mathrm{PsP}_{\mathrm{L}}$ 14.1-3), translation and comments:

$\bar{a} c \bar{r} r y a b u d d h a p \bar{a} l i t a s$ tv āha na svata utpadyante bhāvās tadutpādavaiyarthyādatiprasaingadoṣāc $\mathrm{ca}^{10} \mid$ na hi svātmanā vidyamānānām padārthānām

8 MMK 1.1: na svato nāpi parato na dvābhyām nāpy ahetutah / utpannā jātu vidyante bhāvāh kvacana kecana // (ef. $\mathrm{PsP}_{\mathrm{L}}$ 12.13-14).

9 I understand prasangavākya as a technical term and therefore translate it as "a statement of [unwanted] consequence," and not, as it often is translated, as "a statement of a consequence" or, as Oetke does (2003: 114), "a statement of [undesired] consequences" (my italics).

10 I follow LVP in emending the text to include this $c a$. None of the mss. attest a $c a$; all end the previous compound with either ${ }^{\circ} d o s \bar{a} t$ or ${ }^{\circ} d o s \bar{a} n$. PsP Tib, however, attests the dain required by the context, as do BP Tib and PP Tib. The repeated copying of cca akșaras often results in the lower ca coming to resemble a small blur. In the present case, in part because the akșara precedes a danda, the lower blur must have been read as the virāma for a slightly deformed $t$ or $n$, or was dropped, a virāma being added later to this akșara interpreted as or resembling a ta or $n a$. 
punarutpāde prayojanam asti | atha sann api jāyeta na kadācin na jāyete$t i \|$

For his part $(t u),{ }^{11}$ the Master Buddhapālita states, "Things do not arise from self because their arising would be pointless (tadutpādavaiyarthyāt) and because there would be the fault of absurdity ${ }^{12}$ (atiprasangadoșât). For there is no purpose in the re-arising of things [already] existing by [their] own nature. But if [a thing], though [already] existing, would arise [again], it would never not arise."13

The correct understanding of a Sanskrit philosophical text, in addition to the aforementioned tools and prerequisites, also requires familiarity with the use of the conjunctions and particles that mark logical relationships. Oetke, both here in the final sentence of the segment and in a later segment, translates atha with "or"; in the present segment he translates, "Or [one assumes that something] originates although it is [already] existing. [In that case] it should never not originate" (2003: 114). "Or" correctly translates atha $v \bar{a}$, but not atha. atha is commonly encountered in philosophical discussions in the sense of "but if," "if, however." De Jong has already commented on the meaning of exactly

11 Oetke does not translate this $t u$, which is meant to offset Buddhapālita's argument from the one Candrakīrti has just cited from the Madhyamakāvatāra.

12 Oetke translates atiprasanga as "an excess of [undesired] consequences" (Oetke 2003: 114). Buddhapālita, with skye ba thug pa med par 'gyur ba'i phyir (he may have used an expression like *janmānisțāpatteh) intends just one consequence, viz., an eternal arising of the existing thing, and not a multitude of mutually differing consequences. Candrakīrti, if we assume the change from *janmānisthappatteh to atiprasangadoșāt to have been intentional on his part, and not a transmissional error, appears to have reformulated the ground pointing out that things that arise from themselves will never stop arising into one indicating that arising from self, to put it colloquially, "goes 'too far' (ati)," i.e., leads to an absurd situation.

13 BP reads: de la re źig dinos po rnams bdag gi bdag ñid las skye ba med de I de dag gi skye ba don med pa ñid du 'gyur ba'i phyir dan I skye ba thug pa med par 'gyur ba'i phyir ro \| 'di ltar dinos po bdag gi bdag ñid du yod pa rnams la yan skye ba dgos pa med do $\|$ gal te yod kyan yan skye na nam yan mi skye bar mi 'gyur bas de yán mi 'dod de I de'i phyir re źig dinos po rnams bdag las skye ba med do $\left(\mathrm{BP}_{\mathrm{ed}}\right.$ 10.11-17). PP: 'di las gźan ni dinos po rnams bdag gi bdag ñid las skye ba med de I de dag gi skye ba don med pa ñid du 'gyur ba'i phyir dan I skye ba thug pa med par 'gyur ba'i phyir ro I (D without I) zes rnam par bshad pa byed do (D 49a5-6; P 58b7-8). Avalokitavrata informs that 'di las gźan ("the [MMK commentator] different from this [MMK commentator Bhāviveka]") is one of a group of MMK commentators. He lists as MMK commentators Nāgārjuna, Buddhapālita, Candrakīrti, Devaśarman, Guṇaśrī, Guṇamati, Sthiramati and Bhāviveka; he identifies the author of the citation as Buddhapālita (cf. PPṬ D 73a4-6; P 85a7-85b1). 
this atha of Buddhapālita's statement in his review of M. Sprung's translation of the PsP, where he corrects Sprung's "That is, if" to "But if." 14

$\mathrm{PsP}_{\mathrm{M}}$ (cp. $\mathrm{PsP}_{\mathrm{L}}$ 14.4-15.2), translation and comments:

atraike dūșanam āhus tad ayuktam hetudṛ̦tāntānabhidhānāt paroktadoșāparihāāac ca ${ }^{15}$ | prasaingavākyatvāc ca prakrtārthaviparyayena viparīta-

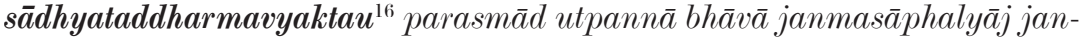
manirodhāc ceti krtāntavirodhah syād iti ${ }^{17} \|$

14 See de Jong 1981: 228. Schmithausen has also explicitly noted that "or" is not an appropriate translation for atha. See L. Schmithausen, Zu D. Seyfort Rueggs Buch "La Théorie du Tathāgatagarbha et du Gotra" (Besprechungsaufsatz). WZKS 17 (1973) 123-160, at p. 149. For atha as "but if," see also Speijer 1988: $\$ 486$. Seyfort Ruegg translates the atha in Buddhapālita's statement as "but if" in his recent translation of the PsP on MMK 1.1. He overlooks, however, that api is intended in a concessive sense, and thus translates it as "also": "But (ii) if (atha $=c i$ ste) the existent also were [once] to be [re]born, never would it not be [re]born" (Seyfort Ruegg 2002: 25).

${ }_{15}$ I follow LVP in emending the text to include this $c a$. None of the fifteen mss. attests a ca; all end the previous compound with either ${ }^{\circ} h \bar{a} r \bar{a} t$ or ${ }^{\circ}$ härāta (on the reinterpretation of cca akșaras, see above n. 10). The mss. read hetudrștāntāna-

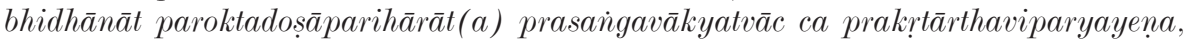
etc. All but ms. P, the palm-leaf ms., place a double danda after hetudrsțāntānabhidhānat, and all, with the exception of one paper ms., place either a single or double danda after paroktadoșāparihārāt. LVP bases his emendation on PsP Tib:

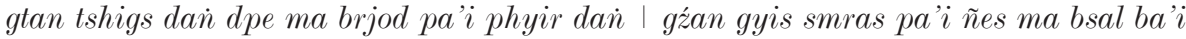
phyir ... ( $\left.\mathrm{PsP}_{\mathrm{L}} 14, \mathrm{n} .5\right)$. On this and the following ca, see the Appendix, point 2.

16 LVP emends to ${ }^{\circ}$ vyaktau (attested in my ms. D), noting that PsP Tib's minon pas would expect as equivalent vyakteh $\left(\mathrm{Ps}_{\mathrm{L}} 15, \mathrm{n} .2\right)$. I imagine that the translators read "vyaktau and understood the locative in the sense of "in view of," and thus "since," as I have. LVP also conjectures viparīt $[\bar{a} r t h a]$ sādhyataddharma on the basis of PsP Tib's bsgrub par bya ba dan I de'i chos bzlog pa' $i$ don, a conjecture I am hesitant to accept - even though the PP translation indicates that artha was included in PP Skt - on account of the fact that an assumed loss of the aksara parts $\bar{a}$ and $r$ th is difficult to explain and because the compound viparitasādhyasädhanavyaktir is attested later in the text (cf. $\operatorname{PsP}_{\mathrm{L}}$ 38.12-39.1, where LVP presents the text as viparita...vyaktivākyārthah. His reading must be emended to viparita...vyaktir vākyārthah). One also notes that the author of the *LT does not appear to have read artha between viparīta and sādhya: prasangetyādi sāphalyād ityantam ekah pakșah prasangaviparyayena viparītasya sādhyasya vyaktinispattih (read vyaktir nispattih; cf. Yonezawa 1999: 1023). The appearance of don in PsP Tib must be the result of the translators having appropriated the citation directly from PP Tib; on their method of dealing with citations, see p. 163f.

17 All of the mss. but ms. $\mathrm{P}$, which is damaged at this point, attest iti. PsP Tib attests the equivalent źes. 
In regard to this [statement of Buddhapālita's], some ${ }^{18}$ [specifically, Bhāviveka] criticize: "That [argumentation] is incorrect because a reason (hetu) and an example (drsțānta) have not been stated ${ }^{19}$ and because the faults pronounced by the [Sānkhya] opponents have not been refuted. ${ }^{20}$ And because it is a statement of [unwanted] consequence (prasangavākya) ${ }^{21}$ [it follows, ] since through the reversal of the meaning [of the statement] under discussion the opposite of the probandum $(s \bar{a} d h y a)$ and [of] its properties (taddharma) [i.e., the probans] are expressed, [that] there would be contradiction with [your own] accepted tenets (krtāntavirodha), [because your consequence would imply that] 'Things have arisen from other, because [their] arising is purposeful and because arising stops [upon completion of the process of arising]'."22

18 LVP asserts that "eke = Bhāvaviveka-ādayah" $\left(\mathrm{PsP}_{\mathrm{L}} 14\right.$, n. 4). *LṬ's author identifies eke as Bhāviveka: atraika iti Bhāvivekah (cf. Yonezawa 1999: 1023).

19 In regard to prasainga LVP quotes Nyāyavārttikatātparyāṭ̄kā: prasango hi na sādhanam, hetor abhāvāt (see $\mathrm{PsP}_{\mathrm{L}}$ 23, n. 3).

20 Seyfort Ruegg erroneously translates the first two reasons as one, interpreting the first as the ground for the second. He does not provide an explanation for his interpretation. He translates, "That [argument of Buddhapālita's] is unfounded. This is so (i) because, on the one hand, no inferential reason (gtan tshigs) and no instance (dpe) having been provided, no rebuttal has been provided (aparihāra $=m a b s a l b a)$ [by Buddhapālita] of the faults $($ doṣa = nes pa $)$ alleged by the opponent [viz. the Sāṃkhya]" (2002: 26).

${ }_{21}$ On the reading glags yod pa'i tshig (*sāvakāsavacana) in the PP, see the Appendix, Point 3.

22 Candrakīrti is citing from Bhāviveka's PP which reads in translation: de ni

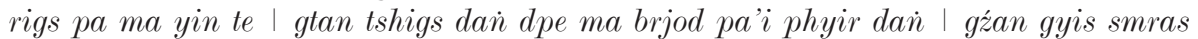
pa'i ñes pa ma bsal ba'i phyir ro \| (D: phyir dan |) glags yod pa'i tshig1 yin pa'i phyir te $\left.\right|^{2}$ skabs kyi don las bzlog pas bsgrub (P: sgrub) par bya ba dan I de'i chos bzlog pa'i don minon pas dinos po rnams gźan las skye bar 'gyur ba dan I skye ba 'bras

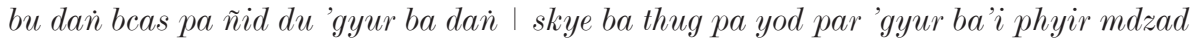
pa'i mtha' dàn 'gal bar 'gyur ro (D 49a6-49b1; P 58b8-59a2; translated in Ames 1993: 222-223; Kajiyama 1963: 50; Yotsuya 1999: 76). PsP Tib: 'thal bar 'gyur ba' $i$ tshig for glags yod pa'i tshig; ' without te I; 'grub pa'i mtha' for mdzad pa'i mtha'. - On LVP's remark that janmanirodhāt does not correspond to PsP's (and PP's) skye ba thug pa ... ( $\mathrm{PsP}_{\mathrm{L}}$ 15, n. 4), see Hopkins 1983: 817, n. 363. For discussions on the third point of criticism, see Hopkins 1983: 490-492; Tillemans 1992: 318ff.; Seyfort Ruegg 1991: 290-296 and n. 35, and, more recently, 2000: 252-265. Bhāviveka is referring to a reversal (viparyaya) in the sense of a reformulation of the probandum "things do not arise from self" into "things have arisen from other" and of the first probans "because their arising would be pointless" into "because their arising is purposeful" and of the second "because there would be a succession without end of arising" (or, as Candrakīrti presents it: "because there would be the fault of absurdity") into "because arising stops." 
Bhāviveka argues, fïst, that Buddhapālita's statement of unwanted consequence is not suitable as an argument against the position of arising from self because it does not include a proper reason and example. Yotsuya has explained why the two grounds in the consequence are not acceptable (1999: 76, n. 10):

In pointing out that entities do not originate from self, Buddhapālita presents the grounds: pointlessness (don med pa, vaiyarthya) and infinite regress (thug pa med pa, anavastha $)$... . These are, however, not considered to be logical reasons, since they are not properties of the subject, i.e. entities. In other words, "pakșadharmatā", which is one of the characteristics of a correct logical reason ... is not established. ${ }^{23}$

Bhāviveka next criticizes Buddhapālita for not having refuted the Sāṅkhya critique of (in Bhāviveka's opinion, a proper) argument against arising from self (cf. Candrakīrti's citation of the Sānkhya critique on p. 160). The specific argument the Sāṅkhyas criticized was of course Bhāviveka's own inference refuting arising from self, which Candrakīrti later cites as na paramārthata ādhyātmikāny āyatanāni svata utpannāni vidyamānatvāc caitanyavat "Ultimately the inner bases have not arisen from self [i.e., from themselves] because [they] are [already] existing, like consciousness."24 Bhāviveka presumes that the inference Buddhapālita should have presented would be liable to the same generally applicable critique of the Sānkhyas and thus faults Buddhapālita for having failed to neutralize it. ${ }^{25}$ Bhāviveka's third

23 More precisely, the grounds are "pointlessness of arising" and "a succession without end of arising."

${ }^{24}$ Candrakinti cites the inference at $\mathrm{PsP}_{\mathrm{L}}$ 25.9-26.1. The reason is given as vidyamānatvāt at $\mathrm{PsP}_{\mathrm{L}} 26.1$, but as sattvāt at $\mathrm{PsP}_{\mathrm{L}} 30.15$ and 33.4. Note that the reason in the second svata evānumāna set forth by Candrakīrti at $\mathrm{PsP}_{\mathrm{L}} 22.4$ is vidyamānatvāt. The reason referred to at $\mathrm{PsP}_{\mathrm{L}}$ 20.5-6 will also have to be construed as vidyamānatvāt (ef. $\mathrm{PsP}_{\mathrm{L}}$ 21.4-5: vidyamānatvena ... hetunā ...). PP Tib translates the inference as don dam par nan gi skye mched rnams bdag las skye ba med par nes te I yod pa'i phyir dper na shes pa yod pa ñid bźin no (PP D 49a2-3; P 58b1-2) "It is ascertained that ultimately the inner bases do not arise from self [i.e, from themselves] because [they] are [already] existing, like consciousness."

${ }^{25}$ Avalokitavrata's interpretation of the second criticism is similar: gźan yá gźan gyis smras pa'i ñes pa ma bsal ba'i phyir te I gal te de la gtan tshigs dan dpe dag brjod cin sgrub pa rdzogs par brjod du zin kyan de la skye bar smra ba gźan gyis smras pa'i ñes pa gdon mi za bar 'byun bar 'gyur na । de yan் khyod kyis (P: kyi) ma bsal bas | de'i phyir gźan gyis smras pa'i ñes pa ma bsal ba'i phyir de ni rigs pa ma yin no \| (PPṬ D 74a1-2; P 86a5-7). Hopkins translates: "Furthermore, [it is not suitable] 'because [the reasoning as Buddhapālita states it] does not avoid the fallacies adduced by another [that is, the fallacies that a Sāmkhya would be expected 
critique assumes that the consequence will yield another, in this case unwished for, meaning when its probandum and probans are reversed.

Oetke's translation of Bhāviveka's second criticism gives the impression that he understands that the Sānkhyas have directly faulted Buddhapālita's consequence, which they certainly have not. He translates: "This is improper, because an inferential reason (hetu) and an example (drsțānta) have not been presented [in Buddhapālita's proof] and because the faults [of that argumentation] which have been pointed out by the opponent (i.e. the defender of the Sāmkhya-position) have not been refuted" (Oetke 2003: 114). He rephrases this second criticism in his summarizing explanation of the section as "the refutation lacks an explicit rejection of the reproach that it is beset by other non-formal defects" (p. 117). He further mistranslates prakrtārthaviparyayena, a compound indicating how the expressing (vyakti) of the opposite of the probandum and probans is brought about (correct translation: "through the reversal of the meaning [of the statement] under discussion"). The compound has to be construed with the entire following compound, and cannot be construed solely with viparita, the first member of the compound, as Oetke would have it. He translates $\mathrm{Ps}_{\mathrm{s}} \mathrm{P}_{\mathrm{L}}$ 's prakrtārthaviparyayena viparīt $[\bar{a} r t h a]$ sādhyataddharmavyaktau as "... a probandum as well as properties of that (i.e. the substratum) emerge which are opposite by being opposed to the pertinent objects/meanings ..." (Oetke 2003: 114).

$\mathrm{PsP}_{\mathrm{M}}\left(\mathrm{cp} . \mathrm{PsP}_{\mathrm{L}}\right.$ 15.3-16.2), translation and comments:

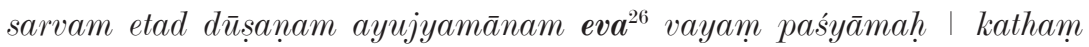
$k r$ tvā $\mid$ tatra yat tāvad uktam hetudrsțāntānabhidhānād iti tad ayuktam | kim kāranam | yasmāt parah svata utpattim abhyupagacchan vidyamānasya punarutpāde prayojanam prcchyate | svata iti vidyamānam ${ }^{27}$ hetutvena bravișisi ${ }^{28}$ tad eva cotpadyata iti na ca vidyamānasya punarutpattau

to adduce'. This indicates that] even if he had fully expressed and established a reason and an example, it would, without question, have the fallacies adduced by another who propounds [ultimately existent] production, but you [Buddhapālita] did not avoid them; therefore, because of not avoiding the fallacies adduced by another, [the explanation] is not suitable" (1983: 464).

26 All of the mss., except for ms. $\mathrm{P}$, which is damaged at this point, attest eva. $\mathrm{PsP}$ Tib is without an equivalent for eva.

${ }_{27}$ Mss. $\mathrm{P}$ and $\mathrm{D}$ attest vidyamanam. PsP Tib attests the equivalent yod pa.

28 Mss. $\mathrm{P}$ and $\mathrm{N}$ attest bravissi, while the rest attest bravisi. PsP Tib reads for the sentence: bdag las źes bya ba ni yod pa rgyu ñid dan de ñid skye'o źes smras pa yin. 
prayojanam paśyāmo 'navasthām ca paśyāmah | na ca tvayotpannasya punarutpāda iṣyate na $^{29}$ cāpy anișthet ${ }^{30}$ | tasmān nirupapattika eva bhavadvādah. ${ }^{31}$ svābhyupagamaviruddhaś ceti |

kim iyati $^{32}$ codite paro nābhyupaiti yato hetudṛstāntopādānasāphalyam syāt | atha svābhyupagamavirodhacodanayāpi $i^{33}$ paro na nivartate tadātinirlajjatay $\bar{a}^{34}$ hetudrṣ̦̄antābhyām api naiva nivarteta | na conmattakena sahāsmākam vivāda iti sarvath $\overline{\boldsymbol{a}}^{35}$ priyānumānatām evātmana ācāryah.

29 All of the mss. attest na. PsP Tib reads thug pa med par yan mi 'dod do for na cāpy aniștheti. LVP conjectures 'na [vasthā] for the mss.'s na because he emends the readings enisteti and enistheti that appear in his mss. (for the following anistheti) to anisteti - taking anista of his emendation anisteti to reflect PsP Tib's mi 'dod - and then requires a Skt basis for Tib's thug pa med pa. aniștha , however, of anistheti was the basis for thug pa med pa. For the sake of clarity the translators have added a translation for the isyate ('dod) that is understood through anuvrtti in the Skt.

30 Ms. P attests the correct reading anistheti. See also the preceding note. Cf: BHSD s.v. anișthāpada.

31 I emend to bhavadvādah on the basis of ms. P's bhavavādah. LVP emended to tvadvādah on the basis of the reading tadavadah in his three manuscripts. LVP considers, in the light of Tib's khyed cag gi rtsod pa, tvadvivādah as an alternate emendation possibility $\left(\operatorname{PsP}_{\mathrm{L}} 15, \mathrm{n} .7\right)$. Candrakīrti has in the previous sentence utilized the pronoun $t v a d$, that is, tvaya , to refer to the Sānkhya opponent. Forms of the pronouns tvad and bhavat may be used promiscuously, and it is common to see them used alternatively, even within the same sentence (cf. Speijer 1988: $\$ 259$ Rem.) The akșara dva is easily read as va in old Nevārī, and bha is frequently confused with $t a$. A $v a$ with damage at the point its oval connects with its vertical stroke can be mistaken for $d a$. tadavādah would thus have entered the ms. tradition when bha was read as $t a, v a$ as $d a$, and dva as $v a$.

32 Ms. P attests the previously unconfirmed iyati that Yotsuya has suggested for LVP's conjecture tanmātrena (1999: 57). LVP's conjecture tanmātrena was based on Tib's 'di dag tsam źig gis $\left(\mathrm{PsP}_{\mathrm{L}} 15, \mathrm{n} .8\right)$. De Jong, reading the corrupted iyati of ms. D as iryacc(?) iti (I read it as iryavr[?]iti), had earlier tentatively suggested iyad iti (1978: 29).

33 Following LVP, I emend the mss.' readings ${ }^{\circ}$ viruddha ${ }^{\circ}$, ${ }^{\circ}$ diruddha ${ }^{\circ}$ to ${ }^{\circ}$ viro-

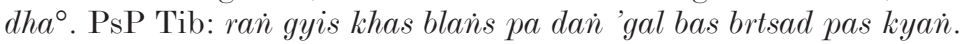

34 Mss. $\mathrm{P}$ and $\mathrm{D}$ attest the correct reading $t a d \bar{a} t i^{\circ}$. The other thirteen mss. attest tada $p i^{\circ}$. PsP Tib does not attest an equivalent for ati, but the prefix ati is sometimes left untranslated. Tib also does not attest an equivalent for api, and it would be quite unusual for an api after $\operatorname{tad} \bar{a}$ to be ignored. It is anyway difficult to make sense of an api here.

35 All of the mss. attest sarvathā or variations of it. LVP has emended to tasmāt under the influence of 'Tib's de'i phyir. The previous $i t i$ appears to have been translated as de'i phyir and sarvath $\bar{a}$ was either purposely not translated or overlooked. Yotsuya also emends to sarvatha on the basis of his ms. material and Tanji 1988 (see Yotsuya 1999: 57 and n. 34). 
prakațayaty asthāne 'py anumānam praveśayan | na ca mādhyamikasya svatah svatantram anumānam kartum yuktam pakṣāntarābhyupagamābhāvāt \|

$W^{36}$ view this entire critique as being quite incorrect. Why? That alleged first in it, namely, "because a reason and an example have not been stated," is inapplicable. For what reason? Because [with Buddhapālita's statement] the [Sānkhya] opponent maintaining arising from self is questioned as to the purpose of the re-arising of something [already] existing: ${ }^{37}$ [When you say] "from self" (svatah), you assert something [already] existing to be the cause (hetutvena) and [assert that] exactly that arises; but we do not see [any] purpose in the arising again of something [already] existing, and we see $^{38}$ [in this claim of the arising of things already existing] an infinite succession (anavasth $\bar{a}) .{ }^{39}$ And you

36 *LṬ: vayam iti Candrakīrttih. Immediately before this clarification, *LṬ's author comments that Bhāviveka is said to be a proponent of independent proofs:

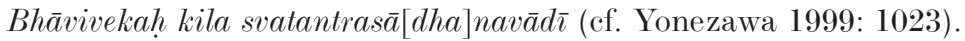

37 Tib without an equivalent for vidyamānasya punarutpāde prayojanam. It may have been dropped by the translators because pha rol po bdag las skye bar 'dod pa la 'dri bar byed pa yin (= parah svata utpattim abhyupagacchan prcchyate) has for the sake of the Tibetan syntax been placed not before the argumentation beginning with svata iti vidyamānam hetutvena braviși, but after the final conclusion tasmān nirupapattika eva bhavadvādah svābhyupagamaviruddhaś ca. The translators may have considered that this placement of pha rol po bdag las skye bar 'dod pa la 'dri bar byed pa yin made vidyamānasya punarutpāde prayojanam irrevelant, or misleading, since a lack of purpose relates only to the first part of the argumentation in the Skt, and represents only one of the consequences of arising from self, the second also having been stated in the Tib before pha rol po bdag las skye bar 'dod pa la 'dri bar byed pa yin appears. The restructuring of the passage is not completely satisfactory, though, because it presents the opponent as being directly asked the argumentation (... zes pha rol po ... 'dri bar byed pa yin), whereas in the Skt the opponent is "questioned" in regard to the purpose of re-arising in the form of being challenged by its consequence. - Seyfort Ruegg has failed to notice that pha rol po bdag las skye bar 'dod pa la 'dri bar byed pa yin is indeed included in PsP Tib. He translates: "This is because, < < origination] from self being accepted by the [Sāmkhya] opponent who is questioned (prcchyate) as to the purpose of renewed origination [not in Tib.]>, ..." (2002: 27).

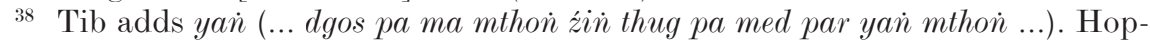
kins translates, "and we also see ..." (1983: 474).

39 Cp. Candrakīrti on CŚ 11.10: yadi hi tasyāstitvam syāt tadā sato vidyamānasya punar api janma syāt [I] na ca satah punar api janma nyāyyam nihprayojanatvāt [।] aniș̣thāprasaingād $\bar{a}$ samsāaram ekasyaivārthasya punar utpādenāparisamāptodayasya satas tatpadārthāntarāpravrtter hetuphalabhāvavyāghātah syāt (CŚ'T ${ }_{\text {ed }}$ 228.1418; see also CŚ́T ed 228, n. 13). 
do not assent to the arising again of what has arisen, nor to a succession without end $($ anisth $\bar{a})$. Therefore, your assertion [that things arise from self] is simply ${ }^{40}$ illogical (nirupapattika), and is contradicted by what [you your]self [otherwise] maintain (svābhyupagamaviruddha).

Is [it reasonable to assume,] when [he has been] censured to such an extent (iyati codite), ${ }^{41}$ that the [sensible] opponent does not accept (i.e., that he rejects) [our criticism], so that the employment of a reason and an example might [in fact] be useful (sāphalya)? [No, he accepts it, of course!] But if the opponent does not withdraw even with the censure $(\operatorname{codan} \bar{a})$ that there is contradiction with what [he him]self maintains, then out of [his] extreme shamelessness (atinirlajjatā) he would certainly not withdraw even with [our resorting to] a reason and example. And we do not debate with a madman (unmattaka). Thus, the Master [Bhāviveka], ${ }^{42}$ introducing an inference even when it is inopportune (asthāna), reveals nothing but his liking - at all costs $($ sarvatha $)$ - for inference. ${ }^{43}$ But because he does not maintain any other position (pakșa), it is not right for a Mādhyamika himself ${ }^{44}$ to construct an independent inference (svatantram anumānam).

On account of the various emendations that need to be made to the $\mathrm{PsP}_{\mathrm{L}}$ text for this segment, I shall limit my comments on Oetke's $\mathrm{PsP}_{\mathrm{L}^{-}}$ based translation to the most fundamental. Most distressing to the conscientious philologist, or to anyone else, for that matter, who wishes to know what Candrakīrti said, is Oetke's complete disregard - here and throughout this entire section preceding the passage of interest of the emendations made to the $\mathrm{PsP}_{\mathrm{L}}$ text by de Jong on the basis of the important Rome ms. (I refer to it as "ms. D") over a quarter of a

40 Tib without an equivalent for eva, possibly because the translators understood it as a mere predicate-marker.

${ }^{41}$ Although the subject of the locative absolute iyati codite is actually iyat, for the sake of the English I translate as above. 'di dag of 'Tib's 'di dag tsam źig gis brtsad pa na appears to be the translators' specification of exactly what "to such an extent" (iyat) refers back to, namely, either the two consequences utpādavaiyarthyāt and *janmānișthāpatteh stated by Buddhapālita (cf. n. 12, above), or the nirupapattika(tva) and svābhyupagamaviruddha(tva) implied by the consequences. The fact that sväbhyupagamavirodha is referred to in the following sentence may indicate that the translators meant the latter pair.

42 *LṬ's author identifies the "Master" as Bhāviveka: ācārya iti Bhāvivekah (cf. Yonezawa 1999: 1023).

43 I construe sarvathā with priyānumānatām. On PsP Tib's reading, see n. 35.

44 PsP Tib without an equivalent for svatah: dbu ma pa yin na ni ran gi rgyud kyi rjes su dpag par bya ba rigs pa yai ma yin te. 
century ago and, more recently, by Yotsuya on the basis of further manuscript material..$^{45}$ Incorporation of these hard-won emendations would have at least spared the reader having to grapple with the translation "... because the (Sāmkhya-)opponent ... is asked about the use [which might be fulfilled] if a re-origination of something [already] existing [occurred], since [the expression] 'from itself' [means that it exists] as a cause and [on the other hand] that very thing originates" (Oetke 2003: 115). Even though Oetke issues two disclaimers for his sole reliance on $\mathrm{PsP}_{\mathrm{L}}{ }^{46} \mathrm{I}$ fail to comprehend just how a mode of procedure that ignores potentially important textual readings can be reconciled with the mode of procedure that carefully takes all details into consideration. I admit that the texual changes ignored here by Oetke do not substantially affect the interpretation of the $\mathrm{PsP}_{\mathrm{L}}$ 19.3-7 passage, but this fact hardly justifies the reproduction of what now has to be considered a corrupt text.

The first sentence of the second part of this segment is intended as a rhetorical question. I supplement my translation of the sentence with bracketed material and add the presupposed answer to the question in brackets for the sake of illuminating the sense intended by Candrakīrti. The other interpretations liable to be suggested by the $\mathrm{PsP}_{\mathrm{L}}$ text may be found in previous translators' renderings of the sentence. One of the main (mis)interpretations, propagated initially by Stcherbatsky (in part under the influence of LVP's conjecture tanmātrena), takes Candrakīrti to be asserting that the opponent does not accept this "mere" critique, i.e., the "mere" pointing out of the consequences that follow from the Sānkhya position of arising from self, and that a more effective method, the employment of an inference with a correct logical reason and example, is definitely required to convince the opponent that he is in error. Stcherbatsky translates, "Now, (you think) that if (the Sānkhya), our opponent, is assailed merely in this way, he will not yield (to our onslaught), and an (other) reason with example is needed

45 Cf. de Jong 1978 and Yotsuya 1999.

46 Before presenting the $\mathrm{PsP}_{\mathrm{L}}$ text, Oetke states, "It seems that the foregoing passage beginning with p. 14,1 according to de La Vallée Poussin's edition contains everything which is relevant for an assessment" (Oetke 2003: 112-113); before presenting his translation, he states, "Assuming that this text is sufficiently reliable at least for the relevant purpose of reconstructing the argumentative situation ..." (ibid., p. 114). 
in order to make it (more) efficacious." ${ }^{77}$ This and other Stcherbatskystyle translations, however, must all implicitly assume a smuggled-in na at the beginning of the sentence, which will allow the sentence to be interpreted as "Is it not the case that ... the opponent does not accept [the criticism], so that ...?" (and thus the assertion: "... the opponent does not accept [the criticism], so that ... ."). The recent translation by Seyfort Ruegg does not assume an illicit na, but it also does not appear to be reflecting the rhetorical question intended by Candrakinti. Seyfort Ruegg translates, "[Now Candrakīrti observes regarding Bhavya's criticism of Buddhapālita:] Having been challenged (codita = brtsad pa) this much [by the Mādhyamika following Bhavya's prescription], does the [Sāmkhya] opponent (para = pha rol po) not [any longer] maintain his position $(n \bar{a} b h y u p a i t i=$ khas len par mi byed dam $)$, so that the admission $(u p \bar{a} d \bar{a} n a=b k o d p a)$ of an inferential reason and an instance might [then, had Buddhapālita provided them, turn out to] have a use (yato hetudrsțāntopādanasāphalya) [in the Mādhyamika's debate with the Sāṃkhya]?"48 If I understand him correctly, Seyfort Ruegg takes Candrakīrti to be merely asking if (and perhaps implying that) the Sānkhya will abandon his position, and indicating that the quitting of the position is the circumstance that makes the inference a useful tool. This interpretation of the main clause, however, and the interpretation that takes the main clause as implying that the opponent does accept the critique (i.e., the sentence is read as "... does the opponent not accept

47 Cf. Stcherbatsky 1927: 17; 1989: 100. Yotsuya presents three translations that are in this general pattern (1999: 56, n. 27; none of the three translations interpret yatah as having a consecutive function).

48 Seyfort Ruegg 2002: 27-28. I do not understand why Seyfort Ruegg relates the "challenge" to a Mādhyamika who follows Bhāviveka's prescription; Candrakīrti has merely restated the consequences that Buddhapālita has said are entailed by the position of arising from self and made more explicit why they force the Sānkhya to abandon this position. It is also not clear to me why he considers Candrakīrti to be speaking sarcastically in the passage (see p. 27, n. 13). If he connects a sarcastic tone with only the sentence under discussion, it is possible that he considers Candrakīrti to be saying that the Sānkhya will not accept the critique, and therefore the reason and example will not be of any use - thinking that the Sānkhya must have accepted the critique for the inference to come across effectively. This interpretation would reflect awareness of the fact that Candrakinti intends in this passage to reject that inferences are of any use. The problem with the interpretation is that it implies that Buddhapālita's consequences are not capable of dissuading the Sānkhya from his view and that independent inferences have a role to play once the opponent has relinquished his position. 
..., so that ..."), which views the consecutive clause as indicating what ensues from the acceptance of the critique, namely, the employment of a reason and example becoming useful, meet with difficulties. First, it will have to be explained just what would be accomplished with the trotting out of an inference after the opponent has recognized his mistake and relinquished his position. Second, the segment now contains a glaring contradiction, for with the sentence under discussion Candrakīrti will be assenting to the Mādhyamika's use of independent inferences in cases of opponents who give up their original position, but with the segment's final sentence he emphatically denies that independent inferences may ever be utilized.

The consecutive clause of the sentence has to be understood as indicating what might be considered to be of value if the opponent does not accept the criticism. ${ }^{49}$ Since the entire sentence is intended as a rhetorical question, it implies that the opponent accepts the criticism, and thus has no need of independent inferences. Even though it seems to be suggested with the sentence that an inference would be valuable when one is dealing with opponents who do not accept the critique, Candrakīrti immediately, with the following sentence, or rather alternative (note the use of atha), rejects the implication by stating that there is in fact no point in trying to convince such foolish opponents by way of inferences. Thus, with the first alternative, it is communicated that any reasonable Sānkhya opponent will promptly renounce the position of arising from self when confronted with the consequences of this position, without needing to be served up a formal inference, and with the second, it is declared that the Sānkhya opponent who refuses to abandon the position of arising from self even when faced with its un-

49 I am aware that Yotsuya understands the sentence as I do, but unfortunately his translation is not unambiguous. He translates, "When [the opponent (= the Sāmkhya)] is censured to such an extent, why [should] the opponent not

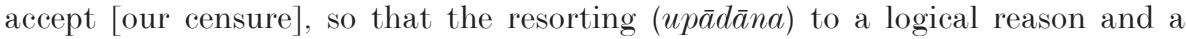
logical example would be purposeful (sāphalyam)?" (1999: 56). Hopkins, too, understands the sentence as a rhetorical question implying that the opponent will accept the censure, but the structure of the Tibetan has caused some confusion. He translates, "When [Buddhapālita] debates through just these [consequences] which have the effects [derived] from stating a reason and example, would the opponent not accept it?" (1983: 474). The Tibetan reads: gain las gtan tshigs dain dpe bkod pa 'bras bu dan bcas par 'gyur ba 'di dag tsam źig gis brtsad pa na ci pha rol po khas len par mi byed dam I. 
acceptable consequences is such a bonehead that he will also not be swayed by full-fledged inferences. In neither case is an independent inference of any benefit. The two sentences constitute Candrakīrti's first argument in defense of Buddhapālita's reliance on statements of [unwanted] consequence (prasaingavākya) and against Bhāviveka's claim that these are unacceptable and need to be replaced by, or at least supplemented with, independent inferences.

Oetke, apparently oblivious to Yotsuya's emendation iyati, translates the first sentence as: "If only so much is brought forward [against him], what is there which the opponent does not [yet] admit, so that the mention of an indicating reason and an example might fulfil some purpose?" (Oetke 2003: 115). It is not completely clear to me how he understands the question. He appears to see Candrakīrti merely asking what, if anything at all, remains in doubt and thus requires an inference to be eliminated. It is possible to read his translation as verging on a rhetorical question, but his acceptance of LVP's tanmātrena ("only so much") makes the sentence ambiguous, and just as easily read as one implying that the critique is not quite sufficient. He translates the atha introducing the second sentence, as earlier, with "or," and on account of this translates what is actually the protasis of the conditional sentence as an independent question, and the apodosis of the same conditional sentence (commencing with $\mathrm{PsP}_{\mathrm{L}}$ 's $\operatorname{tad} \bar{a} p i^{50}$ ) as a new, independent sentence. He translates: "Or is it so that the opponent is not brought to abstain from his views even by pointing out to him a contradiction concerning that which he himself accepts? Even then [it holds good that] because of his shamelessness not even reasons and examples would make him give up his view" (Oetke 2003: 115).

$\mathrm{PsP}_{\mathrm{M}}$ (cp. $\mathrm{PsP}_{\mathrm{L}}$ 16.11-18.4), translation and comments:

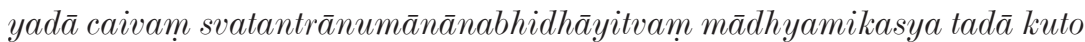
nādhyātmikāny āyatanāni svata utpannānīti svatantrā pratijñā yasyām sāं $k h y \bar{a} h$ pratyavasthāsyante

50 Yotsuya, who also did not have access to ms. P or ms. D, which read tad$\bar{a} t i n i r l a j j a t a y \bar{a}$ where the other manuscripts present the more problematic tada $p i^{\circ}$, more sensibly translates the $\mathrm{PsP}_{\mathrm{L}}$ text as "But if the opponent (= the Sāmphya) does not even withdraw ..., in this case, too, he will hardly withdraw ... (1999: 56). De Jong has not noticed that ms. D reads tada $t i^{\circ}$, and therefore does not suggest the emendation in his "Textcritical Notes." 
ko 'yam pratijñārthah kim kāryātmakah ${ }^{51}$ svata uta kārañātmaka ${ }^{52}$ iti

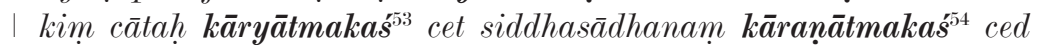
viruddhārthatā kāran̄ātmanā vidyamānasyaiva sarvasyotpattimata ut$p \bar{a} d \bar{a} d$ iti $\|$

kuto 'smākam vidyamānatvād iti hetur yasya siddhasādhanam ${ }^{55}$ viruddhārthat $\bar{a} \mathrm{va}^{56}$ syād yasya siddhasādhanasya yasyāś ca viruddhārthatāyāh parihārārtham yatnam kariṣyāmah | tasmāt paroktadoṣāprasañgāa ${ }^{57}$ eva tatparihāra ācāryabuddhapālitena $\boldsymbol{n a}^{58}$ varnañ̄yah \|

And ${ }^{59}$ when the Mādhyamika does not state an independent inference (svatantrānumāna) in this way, how [could there possibly be] an independent thesis (svatantrā pratijñ $\bar{a}$ ) [like Bhāviveka's, viz.,] "The inner bases (āyatanāi) have not arisen from self," ${ }^{60}$ in regard to which the Sānkhyas could object:

What is the meaning here of the thesis? Do [you deny that a thing that already] has the nature of an effect (kāryātmaka) [arises] from

51 Thirteen of the mss., including ms. P, attest kāryātmakah; two attest $k \bar{a}$ ryānmakah. LVP emends to kāryātmakāt on the basis of PsP Tib's 'bras bu'i bdag ñid las. PsP Tib reads for the first sentence: ci bdag las źes bya ba 'bras bu'i bdag ñid las sam | 'on te rgyu'i bdag ñid las yin graí |.

${ }_{52}$ Thirteen of the mss., including the palm-leaf ms., attest kāranātmaka; two attest kāranānmaka. LVP emends to kāranātmakād on the basis of Tib's rgyu'i bdag ñid las.

53 Fourteen of the mss., including the palm-leaf ms., attest kāryātmakaś; one attests kāryātmakeś. LVP emends to kāryātmakāc on the basis of 'Tib's 'bras bu'i bdag ñid las.

${ }^{54}$ All of the mss. attest kāranātmakaś. LVP emends to kāranātmakāe on the basis of Tib's rgyu'i bdag ñid las.

${ }^{55}$ Following LVP, I emend the text to include siddhasādhanam, which is required by the context. All of the mss. lack siddhasādhanam. PsP Tib attests grub pa la sgrub pa ñid.

${ }_{56}$ Following LVP, I emend the text to include the necessary $v \bar{a}$. All the mss. lack $v \bar{a}$. PsP Tib attests dam.

${ }_{57}$ LVP's conjecture ${ }^{\circ}$ doșāprasaingād, made on the basis of PsP Tib (thal bar mi 'gyur ba), is confirmed, as has already been noted by de Jong in his "Textcritical Notes," by ms. D.

58 Ten of the mss., including the palm-leaf ms., attest na. LVP conjectures na on the basis of PsP Tib (brjod par bya ba ma yin no) but has overlooked that one of his three mss. attests na.

59 Tib without an equivalent for $c a$.

60 "The inner bases have not arisen from self" is the proposition of the independent inference constructed by Bhāviveka to prove non-arising from self (see p. 151 and n. 24). 
self (i.e., reproduces itself) or [do you deny that a thing that still] has the nature of a cause (kāranātmaka) [arises from self] (i.e., reproduces itself) ? ${ }^{61}$ And what [will follow] from this? If [you deny that a thing that] has the nature of an effect [reproduces itself], there is the proving [by you the Mādhyamika] of what is [already] established (siddhasādhana) [for us Sānkhyas]. If [you deny that a thing that] has the nature of a cause [reproduces itself], [then] the content/meaning [of your thesis] is contradicted (viruddhārthatā), because only as something existing with the nature of a cause does all that arises (utpattimat) arise. ${ }^{62}$

$\mathrm{How}^{63}$ could there be for us (the Mādhyamikas) the reason (hetu) "because [they] are [already] existing" (vidyamānatvāt), which [the Sānkhyas claim] would have [the fault of] proving what is [already] est-

61 Note that PP Tib and PsP Tib attest a źes bya ba after bdag las for which no equivalent iti is found in PsP Skt (ci bdag las źes bya ba 'bras bu'i bdag ñid las sam I 'on te rgyu'i bdag ñid las yin graí). It is difficult to know if zes bya ba is reflecting an iti that actually stood in PP Skt or if it represents an addition or interpretation of the PP Tib translators. A translation for the final iti, on the other hand, is not attested.

${ }^{62}$ The objection appears in the PP as follows: 'dir grains can dag las kha cig phyir zlog par byed de I dam bcas pa 'di'i don gan yin I ci bdag las źes bya ba 'bras bu'i bdag ñid las sam | 'on te rgyu'i bdag ñid las des cir 'gyur' | gal te 'bras bu'i bdag

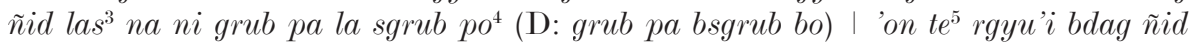
las ${ }^{6}$ na ni don 'gal ba ñid de $e^{7}$ skye ba can thams cad ni rgyu’i bdag ñid du yod pa kho na las skye ba'i phyir ro źe na (D 49a3-5; P 58b3-5; cf. Kajiyama 1963: 49; Ames 1993: 222); PsP Tib: 'dam bca' ba'i don 'di for dam bcas pa 'di'i don; ${ }^{2} y i n$ grai | de las cir 'gyur | for des cir 'gyur |; ${ }^{3}$ adds following yin; ${ }^{4}$ grub pa la sgrub pa yin la for grub pa la sgrub po; ${ }^{5}$ omits 'on te; ${ }^{6}$ adds following yin; ${ }^{7}$ gal ba'i don ñid du 'gyur te for don 'gal ba ñid de; ${ }^{8}$ skye ba dan ldan pa for skye ba can; ${ }^{9}$ without las. This section as found in the PsP is reproduced, translated and commented on in Yotsuya 1999: 61-64. Bhāviveka deals with the objection in the PP by declaring it inapplicable, since he negates mere (tsam) arising from self (see PP D 49a5; P 58b56). - On the Sānkhya theory of the manifestation of all entities from the "Urmatter" prakrti, see, e.g., Frauwallner 1984: 275ff., 303-307; Chakravarti 1975: 215-221; Larson - Bhattacharya 1987: 100-101, 246-249. That the Sānkhyas hold that an effect is not substantially other than its cause is declared, e.g., at YD 109.13-14: na hi nah kārañād arthāntarabhūtam kāryam utpadyata ity abhyupagamah. An effect is merely the differentiated manifestation of the subtle undifferentiated cause: idānīm sattvam rajas tamah puruṣa iti padārthacatuștayam pratijñāyate I tatrāpi purusakartrtvam pratyākhyāyate | tasmin pratyākhyāte gunānām evāvasthāntarāpekṣah kāryakāraṇabhāvah | sūkșmāṇām mūrtilābhah kāryam | nivṛttaviśeșānām avibhāgātmanāvasthānam kāraṇam ity ayam siddhāntah (YD 62.8-12).

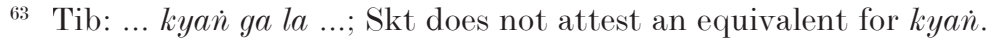


ablished or [the fault of] contradictoriness, ${ }^{64}$ so that we would have to endeavour to refute this proving of what is [already] established and contradictoriness? ${ }^{65}$ Therefore, simply because the faults adduced by the [Sānkhya] opponents do not entail, the Master Buddhapālita does not need to describe their refutation (tatparihāra).

In this segment, Candrakīrti cites (with modifications) the Sānkhya critique of Bhāviveka's independent inference that appears in the PP. Here in the PsP citation the Sānkhyas state that if the Mādhyamika intends to argue that something already existing with the nature of an effect does not reproduce itself, then the inference refuting arising from self would prove what is already established for the Sānkhya (siddhasādhana), because the Sānkhya rejects that things already existing as effects reproduce themselves, e.g., that a pot that has already manifested reproduces itself. In the second case, given that it is a fundamental Sāñkya presupposition that things exist with the nature of a cause and then arise, i.e., manifest, if the Mādhyamika intends to argue that things existing with the nature of a cause do not reproduce themselves, the thesis ends up being contradicted, because only things that exist in a non-manifest state, that is, exist with the nature of a cause, arise.

LVP emended the masculine singular nominative forms kāryātmaka and kārañătmaka of the Sānkhya objection (kāryātmakah, kārañātmaka,

${ }^{64}$ The term used here in the PsP to indicate the contradictory reason is viruddhārthata "being [an inference] whose meaning is contradicted." The contradictory reason (viruddho hetuh) is a fallacious reason (hetvābha $s a)$ in that it proves the opposite of what one intends to prove; cf. NM 4's comm. (Tucci 1930: 23f.) and NM 9 (= PS III.27: chos dan chos can ran n்o bo / yan na de yi khyad par rnams // phyin ci log tu sgrub pa'i phyir / gnod med pa la 'gal ba yin // "It is, when there is no incompatibility [with the proposition], a contradictory [reason] because it proves the opposite of the own-form or the characteristics of the subject or its attribute"; cf. Tucci 1930: 35; Katsura 1979: 78f.; cf. also Tucci 1929: 481). For example, the reason "because it has horns" in the inference "The animal coming is a horse, because it has horns" does not prove that the animal is a horse; it actually proves that the animal coming is a cow.

${ }_{65}$ Cf. Yotsuya 1999: 63, n. 61. Seyfort Ruegg translates the last part of the sentence, which has a consecutive sense, as a separate sentence, and thereby brings in a meaning unintended by Candrakīrti. He translates the sentence as "How, for us [Mādhyamikas], could there be ... for which there might exist [the fault of either] siddhasādhana or viruddhārthat $\bar{a}$ ? We will [indeed] seek to avoid any [argument] incurring [the faults in debate of either] establishment of the [already] established or a sense that is contradictory" (2002: 30). 
kāryātmakaś, kārañatmakaś) that he found in his manuscripts to their corresponding ablative forms because PsP Tib's bras bu'i bdag ñid las (for PsP Skt's kāryātmakah and kāryātmakaś) and rgyu'i bdag ñid las (for PsP Skt's kāranātmaka and kārañātmakaś) appeared to be reflecting ablatives. Although the masculine singular nominative forms are also attested in de Jong's manuscript (my ms. D) and in the three mss. Yotsuya consulted, neither de Jong nor Yotsuya called LVP's emendations into question, almost certainly because they too were of the opinion that PsP Tib's presentation of translations for Sanskrit ablatives, and not nominatives, justified the emendations. No doubt further justification was seen in the fact that the (inextant) PP Skt, from which Candrakīti is citing the objection, was assumed to have attested ablatives since PP Tib likewise contains translations for ablative forms. It has thus seemed reasonable, on the basis of the evidence provided by the Tibetan translations, to view the PsP Skt manuscript readings as corrupt. Disturbing, however, is the appearance of the nominative forms even in the valuable palm-leaf manuscript of the $\mathrm{PsP}$ (my ms. $\mathrm{P}$ ), and the difficulty one has in explaining the causes of the supposed corruption.

These and similar problems and discrepancies in other citations in the first chapter of the $\mathrm{Ps} \mathrm{P}$ inspired me to undertake an analysis of all of the cited material in the first chapter. This analysis has revealed, against the to-date unquestioned assumption that the citations in PsP Tib were translated directly from PsP Skt, that Mahāsumati and Patshab ñi-ma grags, the scholars responsible for the translation of PsP Tib, did not translate the sütra or śasstra citations they encountered in the Sanskrit text. Instead, probably for the sake of consistency, they used the "cut-and-paste" method: They located the translated source texts, looked up the citation, and copied the premade translation of the citation directly into PsP Tib. ${ }^{66}$ I elaborated on their techniques in a recent paper entitled "From Prasannapadā to Tshig gsal: Remarks on an 11th/12th Century Translation Project," presented at the Thirteenth Conference of the International Association of Buddhist Stud-

66 They occasionally made minor modifications to the cited material; see, e.g., n. 22. The modifications were made for various reasons: in certain cases the translators appear to be updating the terminology, in others they merely appear to prefer another word or phrase, in yet others they change the text to make it better accord with Candrakīrti's wording. 
ies; interested readers will find more detailed comments on their techniques in the introduction to my upcoming publication of the first chapter of the PsP. One of the consequences of the detection of the translators' method for reproducing PsP Skt's cited material is that PsP Tib, which reflects Candrakīrti's own words with great precision, has to be divested of some of the confidence normally placed in it as faithful rendering of and therefore as a check for PsP Skt's cited material. Accordingly, to return to the textual segment above, we can no longer be reasonably confident that PsP Tib's bras bu'i bdag ñid las and rgyu'i bdag ñid las indicate that PsP Skt's four nominatives are corruptions in need of emendation; bras bu'i bdag ñid las and rgyu'i bdag ñid las rather have to be seen as the result of this part of the citation having been copied word for word from PP Tib. Because PsP Tib is not a trustworthy witness for this citation in PsP Skt, and for other reasons that will be explained below, I am of the opinion that the nominative forms attested by the Sanskrit manuscripts have to be retained, and contend that the individual responsible for changing what probably indeed were ablatives in the PP Skt to nominatives in the PsP was Candrakīrti.

Besides the fact that Candrakīrti appears to have taken the liberty to make slight modifications in other citations in the first chapter of the PsP, I see more support for my assessment in the citation itself. But before turning to it, a few comments on the contextual backdrop and reasons for the respective nominative and ablative readings are called for. It appears that the change in language in the PsP reflects a shift in what is being taken as the subject that arises, or rather, that is negated as arising. In the pertinent texts, the subject is either the effect (said to arise from itself as its cause), or the cause (said to arise again as its own effect). The ambivalence may already be present in Buddhapālita's argument. His consequence na svata utpadyante bhāvās tadutpādavaiyarthyāt would seem to take things as effects (bhāvas) as the subject and to negate their arising from themselves (as their own cause) because their (i.e., the bhāvas' = the effects') arising would be superfluous. In his explanatory statement na hi svātmanā vidyamānānām padārthānām punarutpāde prayojanam asti, on the other hand, the situation appears to be reversed: Buddhapālita states that it is futile for things already existing as such (i.e., things as cause) to arise again. ${ }^{67}$

${ }^{67}$ This is certainly how Candrakīrti understands Buddhapālita's explanatory statement. Note his introductory sentence to his rewording of the explanatory 
An explicit distinction between things as effects and things as causes is, however, not made by Buddhapālita; he merely refers to things in general. Bhāviveka and Candrakīrti, on the other hand, clearly distinguish the subject that arises as either an effect or a cause. Bhāviveka, who sets forth "the inner bases have not arisen from self" as his thesis

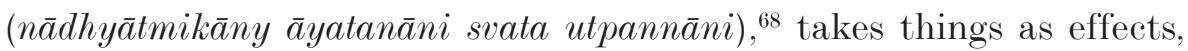
i.e., the (arisen) inner bases, as the subject. Candrakīrti, conversely, takes things as causes as the subject. That his subject of arising is things as causes is supported by his comments later on: in the segment $\mathrm{PsP}_{\mathrm{L}}$ 21.1-6 (see especially 21.3), with his mention of pots and so forth that already exist in a latent state in a lump of clay, etc., he refers to the subject (i.e., locus) of the other-acknowledged inference he draws out of Buddhapālita's statement of unwanted consequence, ${ }^{69}$ in the segment $\operatorname{PsP}_{\mathrm{L}}$ 21.8-12 (see especially 21.10), he makes explicit that what is to be negated as arising are things with a "non-manifest form" (anabhivyaktarūpa); and at $\mathrm{PsP}_{\mathrm{L}}$ 22.1-2, he clarifies that the paksa of the other-acknowledged inference comprises "all things disposed to arise" (niravaśeșotpitsupadārtha).

The two different subjects of arising are respectively alluded to with the ablative and nominative forms of the Sānkhyas' alternatives. Because the Madhyamaka argument denying the arising of things focuses on the Sānkhyas' alleged cause of things (svatah), the Sānkhyas demand that the Mādhyamika provide a more precise description of this cause, namely, as one that has the nature of an effect or one that has the nature of a cause. Thus when Bhāviveka, for whom arisen effects are the subject, is addressed, the Sānkhyas will ask from what type of cause the effects are denied as having arisen. Since Candrakīrti's subject of arising is (already) causes, the Sānkhyas will ask what type of cause is denied as reproducing itself. Candrakīrti therefore modifies PP Skt's

statement (see p. 154): "[When you say] 'from self' (svatah), you assert something [already] existing to be the cause (hetutvena) and [assert that] exactly that arises; but we do not see [any] purpose in the arising again of something [already] existing, and we see [in this claim of the arising of things already existing] an infinite succession (anavasthā)."

68 Cf. $\mathrm{PSP}_{\mathrm{L}}$ 16.11-12. The full inference is cited at $\mathrm{PsP}_{\mathrm{L}}$ 25.9-26.1: $n a p a$ ramārthata ādhyātmikāny āyatanāni svata utpannāni vidyamānatvāc caitanyavat. The conjectures suggested for the word paramārthatah by LVP are confirmed by mss. D and P. See note 24.

69 See p. 172-173. 
*kāryātmakāt and *kāranātmakāt to their nominative forms because he has shifted the subject that arises from things as effects to things as causes. To summarize the questions posed: Inasmuch as PP Skt, PP Tib and PsP Tib take the effect as the subject (i.e., the inner bases), the Sānkhyas there will be asking whether Bhāviveka intends to deny that an effect has arisen from itself as an effect or to deny that an effect has arisen from itself as a cause. In PsP Skt, they are asking whether the intention is to deny that a cause in the state of an effect reproduces itself or to deny that one in the state of a cause reproduces itself.

Awareness of the different perspectives regarding the subject of arising exposes a problem introduced by LVP's emendation of the nominatives to ablatives. In the final sentence of the Sānkhya objection in PsP Skt, it is argued that if the Mādhyamika denies that something with the nature of a cause reproduces itself, the Mādhyamika's thesis is contradicted (viruddhārthatā), "because only as something existing with the nature of a cause does all that arises arise" (kāranātmanā vidyamānasyaiva sarvasyotpattimata utpād $\bar{a} t)$. The subject of arising implied by the sentence is clearly as Candrakīrti takes it to be, i.e., things as causes. This reason given by the Sānkhyas to demonstrate the contradiction appears in PP Tib as skye ba can thams cad ni rgyu'i bdag ñid du yod pa kho na las skye ba'i phyir "because only from something that exists with the nature of a cause ..."; PP Skt may have read kāranātman̄a vidyamāna $d$ eva... . The subject of arising that is implied in this case is Bhāviveka's, viz., things as effects. The allusion to effects as the subject of arising is thus consistent throughout the PP objection. PsP Tib, however, presents the Sānkhya reason showing the contradiction as skye ba dan ldan pa thams cad ni rgyu'i bdag ñid du yod pa kho na skye ba'i phyir. The relevant difference from PP Tib is the lack of a las after rgyu'i bdag ñid du yod pa kho na. The phrase without las brings an unexpected and unacceptable inconsistency to PsP Tib's Sānkhya objection as a whole: in reproducing PP Tib's objection up to this point, ${ }^{70}$ PsP Tib takes things as effects as the subject of arising, but with the reason showing the contradiction, it takes the subject of arising as Candrakīrti does, i.e., as things as causes. This switch in PsP Tib of the subject of arising from effects to causes points to an oversight on the part of the translators. Following their regular procedure for citations, they copied PP Tib's objection into PsP Tib and made their usual minor modifications to the ready-made translation. For the sake of having

70 For PP Tib and for PsP's minor deviations from PP Tib, see n. 62. 
PsP Tib better reflect PsP Skt's phrase giving the reason for the contradiction, they dropped PP Tib's las, but did not notice that this brought an inconsistency into the text of the objection. ${ }^{71}$ The same inconsistency regarding the subject of arising that mars $\mathrm{PsP}$ Tib is introduced to PsP Skt when the four nominatives are changed to ablatives.

Candrakīrti's inclusion of and modification of the PP Skt Sānikhya objection was obviously motivated by his concern with demonstrating that the other-acknowledged inference he draws out of Buddhapālita's statement cannot be faulted by the Sāṅkhyas (cf. LVP 21.8-12). A mere recitation of the PP Sānkhya complaint did not serve his purposes; he reconstructed the $\mathrm{PP}$ objection so that it could be seen as applicable to his own other-acknowledged inference.

Oetke translates the segment in reliance on $\mathrm{PsP}_{\mathrm{L}}$.

$\mathrm{PsP}_{\mathrm{M}}$ (cp. $\mathrm{PsP}_{\mathrm{L}}$ 18.5-9), translation and comments:

athāpi syān mādhyamikānām pakșahetudrșțāntānām asiddheh svatantrā-

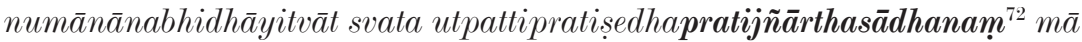
bhūd ubhayasiddhena vānumānena parapratijñānirākaranam parapratijñāyās tu svata evānumānavirodhacodanayā svata eva pakṣahetudrșțāntāpakșālarahitaih ${ }^{73}$ pakṣādibhir bhavitavyam // tataś ca tadanabhidhānāt taddoṣāparihārāc ca sa eva doṣa iti //

Even if it would be [argued]: [It] may [indeed] be, ${ }^{74}$ since the Mādhyamika does not state an independent inference (svatantrānumāna) owing to

71 The translators may have decided not to tamper with PP Tib's version of the Sānkhya question (and accordingly with any of its words restated in the next sentence), or thought that PP Tib's formulation of the Sānkhya question could be construed better with Bhāviveka's pratijñ $\bar{a}$, which had just been referred to, than the PsP Skt formulation could, and therefore refrained from modifying the PP text to reflect the four nominatives.

72 On this emendation, see MacDonald 2000: 172, n. 21. De Jong has already noted that ms. D's pratijñartha is confirmed by Tib's dam bca' ba'i don (1978: 30).

73 On this emendation, see MacDonald 2000: 174, n. 24.

${ }^{74} m \bar{a} b h \bar{u} t$, here in relationship with $t u$, has a concessive sense; see, e.g., the same construction at $\mathrm{PsP}_{\mathrm{L}}$ 273.12-13: nanu ca bhāvānām svabhāvo nāstīty abhyupagacchato $m \bar{a}$ bhüd bhāvadarśanābhāvāc chāśvatadarśanam ucchedadarśanam tu niyatam prasajyate. The translators of PsP Tib have also understood $m \bar{a} b h \bar{u} t$ in connection with $t u$ as intended in a concessive sense ( ma gyur mod); note that Hopkins brings in the concessive sense by translating: "[Bhāvaviveka] might think, "[I might allow that] ... autonomous inferences are not to be expressed ... . Still, ..." (1983: 480). Seyfort Ruegg (see Seyfort Ruegg 2002: 30) and *LṬ's author, on the other hand, interpret $m \bar{a} b h \bar{u} t$ in a prohibitive sense (see MacDonald 2000: 172, n. 22). 
the fact that the proposition $(p a k s a),{ }^{75}$ reason (hetu) and example (drstānta) are not established [for him], that there is neither a proof $(s \bar{a}$ dhana) of the content (artha) of the thesis (pratijñ $\bar{a})$, [in the present case] the negation of arising from self, nor a refutation (nirākarana) of the opponent's thesis by way of an inference established for both [parties of the debate] (ubhayasiddha); nevertheless, there must be criticism $(\operatorname{codanay} \bar{a})^{76}$ of the opponent's thesis for being in contradiction with an inference just ${ }^{77}$ from [his] own (= the opponent's) [point of view] (svata evānumāna) by way of a proposition and so forth that are free of the faults (apakṣala) of the proposition (pakșa), reason (hetu) and example (drsțānta), [each of which is established] only from [his] (= the opponent's) own [point of view]. And ${ }^{78}$ therefore, because those [namely, a proposition together with a reason and example] have not been stated and because their faults [as pronounced earlier by the Sānkhya opponents] have not been refuted, that very fault [remains]. ${ }^{79}$

In the previous segments, the emendations I introduce to the Sanskrit text and the points on which I disagree with Oetke's translation have not had any bearing on the interpretation of the emended version of

75 It is possible that pakșa includes reference to both the subject of the inference and the proposition.

${ }^{76}$ For remarks on the reading codanayā, the *LT reading codanāyām, and PsP Tib's brjod par ni bya dgos pas, see MacDonald 2000: 172, n. 23. Even though the *LT reading is unacceptable, Seyfort Ruegg appears to prefer it, considering it to mean "in view of the explicit ruling/challenge" (cf. Seyfort Ruegg 2002: 30 and n. 19). He translates this part of the sentence, however, following PsP Tib: "Yet ( $m \bar{a}$ bhüt : $\bmod )$, in view of <the need for> an explicit ruling (codana : brjod par ni bya dgos pas) ... there is [still] needed ... a pakșa [, hetu and drsțānta] ... ."

${ }_{77}$ Tib without indication of the -tah suffix and without an equivalent for eva: ran gi rjes su dpag pas.

78 Tib without an equivalent for $c a$.

79 Yotsuya interprets tadanabhidhānāt as a tatpurusa-compound, understanding its tat to refer to criticism by way of a pakșa, etc. He interprets taddosāparihāāa as a tatpurusa-compound with a karmadhäraya-compound as the first member: "these faults $(d o s a)$ [which are raised by the opponent]" (Yotsuya 1999: 64). I interpret taddoṣaparihāāt as a tatpuruṣa-compound with another tatpuruṣa-compound as its first member and thus take tat of both compounds to refer to the elements wanted by the criticism, namely, the pakșa, the hetu and the drstāanta; with this, the original criticism is better reflected in the first compound, and the tat of the second does not require a new referent. *LṬ's author also appears to wish to indicate that both anaphoric pronouns refer to pakșa, hetu and drstāanta: tadanabhidhānāt paksāadyanabhidhānāt / taddoṣah pakṣādidoṣah (cf. Yonezawa 1999: 1023). 
$\mathrm{PsP}_{\mathrm{L}}$ 19.3-7. Here, with $\mathrm{PsP}_{\mathrm{L}}$ 18.5-9, our differences become relevant to the $\mathrm{PsP}_{\mathrm{L}}$ 19.3-7 passage. Oetke's understanding of $\mathrm{PsP}_{\mathrm{L}}$ 18.5-9 definitely appears to have contributed to his far-fetched interpretation of the passage. ${ }^{80}$ Most unexpected is that in reaching his interpretation of $\mathrm{PsP}_{\mathrm{L}}$ 18.5-9, Oetke contravenes his own principle of optimal contextual relevance. Had he not limited the context to be investigated to the few paragraphs preceding the segment of interest and the couple immediately following it (even though the point Candrakīrti wishes to make is, in my opinion, crystal clear in this shorter section), he might have realized that the dispute about inference that takes as its starting point Buddhapālita's statement occurs within a larger context in which one of Candrakīrti's overriding aims is to justify the Mādhyamika's use of inferences which are accepted only by his opponent - and that the present passage is connected with that goal. This larger section commences with Candrakīrti's citation of Buddhapālita's statement of unwanted consequence but ends only at $\mathrm{PsP}_{\mathrm{L}}$ 36.2. Candrakīrti achieves his goal in part by pointing out the problems that attend the Mādhyamika's use of independent inferences; in his lengthy attack on Bhāviveka's independent inference, he elucidates in detail why logical faults will result for the Mādhyamika who uses such inferences in an attempt to comply with the regulation that the components of an inference must be approved by each of the parties in a debate. ${ }^{81}$ At the

so The $\mathrm{PsP}_{\mathrm{L}}$ 18.5-9 segment has been translated correctly by Yotsuya (see Yotsuya 1999: 64) and was paraphrased by me in my previous WZKS article (see MacDonald 2000: 171-172).

81 That the reason and subject must be established for both parties in a debate has been declared by Dignāga in PS III.11 (Skt in PVBh 647.9): dvayoh siddhena dharmena vyavahārād viparyaye / dvayor ekasya cāsiddhau dharmyasiddhau ca nesyate //): "Because one works [in a debate] with a property [of the subject] that is established for the two [parties in a debate], when [this property = the reason] is [assumed to be] the opposite for both or [even] one [of the parties], when [it is] not established [for both or for one] and when the property possessor (= the subject) is not established [for both or for one], [it is] not accepted [as a paksadharma]." At $\mathrm{PsP}_{\mathrm{L}}$ 35.5-6 Candrakīrti cites Dignāga's regulation regarding the reason (hetu) as found in the NM and then advises Dignāga to give it up and rely on Candrakīrti's method. His citation of the NM reads: ya eva tūbhayaviniścitavāci sa sādhanam dūṣanam vā nānyataraprasiddhasam digdhavāc $\bar{\imath}$ (I emend to tūbhaya ...vāci following ms. P's reading; all the mss. attest sādhanam where $\mathrm{P}_{\mathrm{s}} \mathrm{P}_{\mathrm{L}}$ reads pramānam) "Only that [reason], however, which expresses what is ascertained for both [parties in the debate amounts to] a proving element (sādhana) or a refuting element (dūsana), not [one] expressing what is doubtful or what is established for [merely] one of the two [parties]." See the NM commentary to kārikā 2 (Tucci 1930: 15; Katsura 1977: 
conclusion of this large section (the large section, from $\operatorname{PsP}_{\mathrm{L}}$ 14.1-36. 2 , is termed by Candrakīrti a "digression" Lprasanga, $\left.\mathrm{PsP}_{\mathrm{L}} 36.2\right]$ ), the two types of inference are contrasted, the first being referred to as "independent inference" (svatantram anumanam $\left[\mathrm{Ps}_{\mathrm{L}} 34.4\right]$ ), the second as "inference acknowledged exclusively by him[self] (= the opponent)" (tatprasiddhenaivānumānena $\left[\mathrm{PsP}_{\mathrm{L}} 34.6\right]$; the second is also referred to as "inference acknowledged exclusively by oneself (= the opponent)" [svaprasiddhenaivānumānena, $\mathrm{Ps}_{\mathrm{L}}$ 34.10]). In justifying the use of the latter, Candrakirti compares the use of inference to the use of scripture, pointing out that sublation by scripture $(\bar{a} g a m a b \bar{a} d h \bar{a})$ is effected not only by a scripture acknowledged by both parties $(u$ bhayaprasiddha), but also by one accepted only by "oneself" (i.e., by the other party) (svaprasiddha). Here in the segment $\mathrm{PsP}_{\mathrm{L}}$ 18.5-9 Candrakīrti terms the former type of inference "independent inference" (svatantrānumāna) and then again refers to it with the more explanatory wording "inference established for both [parties in the debate]" (ubhayasiddhena vānumanena). The second type of inference is termed "inference just from [his] own (= the opponent's) [point of view]" (svata evānumāna); it is referred to again at $\mathrm{Ps}_{\mathrm{L}} 19.8$ as svato 'numanna. Note that the example (drstānta) for the svato 'numāna that Candrakīrti indicates can be derived from Buddhapālita's statement is referred to at $\mathrm{PsP}_{\mathrm{L}} 20.5$ as paraprasiddha, i.e., acknowledged [only] by the opponent, the Sānkhya.

Now, Bhāviveka presents only independent inferences in the first chapter of his PP, occasionally indicating that their constituents are established for both himself and his opponent, and does not even mention other-acknowledged inferences there, let alone demand one of any of his opponents. Candrakīrti scripts Bhāviveka at $\mathrm{PsP}_{\mathrm{L}}$ 18.7-9 as insisting on the necessity of an other-acknowledged inference because he himself wishes to bring this type of inference into the discussion. His aim in introducing the topic of other-acknowledged inferences is, first, to exonerate Buddhapālita by showing that such an inference is implicit in his statement of unwanted consequence, and, second, to confirm his own approval of and to defend the employment of such inferences. And what better way to bring the other-acknowledged inference into

125f. section 2.4; Katsura emends PVSV to nānyatarāpra ${ }^{\circ}$ [1977: 126]). Cf. also Dignāga's earlier statement in the same commentary to kārikī 2 which declares that the reason must be accepted by both disputants: paksadharmo vādiprativādiniścito grhyate (see Tucci 1930: 13; Katsura 1977: 122). 
the discussion than by having a Madhyamaka master of logic call for it?

The segment $\mathrm{PsP}_{\mathrm{L}}$ 18.5-9, then, opens the way for Candrakīrti to move his "digression" in the direction of other-acknowledged inferences. With the two quotations previous to this segment Candrakīrti has shown that the use of independent inferences presupposes that one has a position positing something ultimately existent or a position which would be based on something being ultimately apprehended by a means of valid cognition; ${ }^{82}$ independent inferences thus cannot be used by Mādhyamikas without violation of their ontological commitment, or, more reflective of their stance, their ontological non-commitment. The segment commences with Bhāviveka conceding that independent inferences cannot be employed by Mādhyamikas because their constituents are not established for the Mādhyamika. But Bhāviveka's concession stops there. Underscoring that his withdrawal of the demand for an independent inference should not be interpreted as consent to the use of statements of unwanted consequence, he now, in the second half of the sentence, insists that an inference of the type admitted only by the opponent (svata evānumāna), i.e., which does not require or imply any ontological commitment on the part of the Mādhyamika, has to be employed. This sort of inference, consisting of a subject, reason and example from the opponent's own stockpile of approved and propounded entities, concepts and tenets, is constructed in such a way that the opponent must accept its thesis; but its thesis will be in contradiction with another thesis of the opponent's, in the present case with the Sānkhya thesis of arising from self. The contradiction made evident by the other-acknowledged inference will force the Sānkhya to relinquish the thesis of arising from self. ${ }^{83}$ Since Buddhapālita, Bhāviveka states, neither set forth such an inference nor refuted the critique the Sānkkhyas are bound to pronounce when one is set forth, he remains at fault. In brief, with the segment $\mathrm{PsP}_{\mathrm{L}}$ 18.5-9 Candrakīrti has Bhāviveka revise his call for an inference from one that commits the Mādhyamika ontologically to one that does not.

Candrakīrti's initial response to the modified demand and critique of Buddhapālita's statement of unwanted consequence is to dismiss it as

82 See Yotsuya 1999: 60.

83 That there is indeed sublation $(b \bar{a} d h \bar{a})$ by an other-acknowledged inference, and that the inference's reason is responsible for this is confirmed and explained at $\mathrm{PsP}_{\mathrm{L}} 34.13 \mathrm{ff}$. 
inapplicable. He gives his reason for this at $\mathrm{PsP}_{\mathrm{L}}$ 19.1-2 (see below). Immediately subsequent to the $\mathrm{PsP}_{\mathrm{L}}$ 19.3-7 passage, however, he has Bhāviveka curtly and firmly reiterate his demand (athāpy avaśyam svato 'numānavirodhadoșa udbhāvanīyah), and with this yields and proceeds to draw an other-acknowledged inference out of Buddhapālita's statement (ef. $\mathrm{PsP}_{\mathrm{L}}$ 20.1-21.6). That this specific other-acknowledged inference is constructed after the pattern of the regular five-membered inference is indicated by Candrakīrti's recitation at $\mathrm{PsP}_{\mathrm{L}}$ 20.7-8 of the stock Nyāya five-membered inference used to refute the Mīmāmasaka tenet of the permanence of sound:

[thesis:] Sound is impermanent, [reason:] because [it] is produced;

[example:] whatever is produced is observed to be impermanent, like a pot;

[application:] and similarly, sound is produced;

[conclusion:] therefore, because [it] is produced, [sound] is impermanent.

After demonstrating how he derives the elements of the other-acknowledged inference from Buddhapālita's statement, Candrakīrti sets forth Buddhapālita's inference in a less formal prose style, as follows $\left(\mathrm{PsP}_{\mathrm{L}}\right.$ 21.2-4):

Here, [the inference implied by Buddhapālita's statement is:] [A thing] such as a pot that is [already] existing by own nature, which is situated in front [of one], is observed not to require re-arising. And similarly $(t a t h \bar{a} c a)$, if you think that [things such as] a pot, etc., are [already] existing by own nature also at the stage of a lump of clay, etc., in this case as well there is not the arising of those [pots, etc., inasmuch as they are already] existing by own nature.

His inference, expressed formally, would be:

[thesis:] [Things disposed to arise (utpitsupadārtha $)^{84}$ such as] a pot, etc., at the stage of a lump of clay, etc., do not require re-arising,

[reason:] because they [already] exist by own nature (vidyamānatvāt); [example:] that which [already] exists by [its] own nature is observed not to require re-arising (punarutpādannapeksa), like [a thing] such as a pot situated in front, which is [already] existing;

[application:] and similarly, [things disposed to arise such as] a pot, etc., at the stage of a lump of clay, etc., [already] exist by own nature;

${ }^{84}$ I supply this specification of the subject of inference following Candrakīrti's comments on the subject at $\mathrm{PsP}_{\mathrm{L}}$ 22.1-2. 
[conclusion:] therefore, because they [already] exist by own nature, [things disposed to arise such as] a pot, etc., at the stage of a lump of clay, etc., do not require re-arising.

The thesis of this inference conflicts with the thesis the Sānkhyas propound, namely, that things arise from self. The Sānkhya will have to accept this inference that proves that things do not arise from self because he certainly does not assume that things such as pots and so forth that sit in front of him arise again; in order to avoid self-contradiction he will be forced to relinquish his thesis of self-arising.

Candrakīrti supplies a second other-acknowledged inference at $\mathrm{PsP}_{\mathrm{L}}$ 22.3-5. This inference is in the Dignāgean three-membered pattern of thesis, reason and example. Here too the subject "things different from Purușa," the reason "because of [already] existing by own nature" and the example "Puruṣa" are admitted only by the Sāṅkhya. Candrakīrti stresses this by inserting "for the [Sānkhya] who claims arising from self (svata utpattivādinah)" after the mention of the subject of inference. $^{85}$

The basic, very general structure of, first, the section to and including $\mathrm{PsP}_{\mathrm{L}} 18.5$ relevant to the present discussion is therefore: 1) Bhāviveka contends that the statement-of-unwanted-consequence method is inappropriate and that Mādhyamikas should adduce independent inferences; 2) a) Candrakīrti defends the statement-of-unwanted-consequence method on the ground that the unwished-for entailments revealed by it suffice to convince the opponent that his position is untenable; b) Candrakīrti rejects the independent-inference method on the ground that a Mādhyamika cannot be involved with inferences that presuppose his assenting to the existence of things; 3) a) Bhāviveka concedes that independent inferences cannot be used by the Mādhyamika but b) contends that other-acknowledged inferences have to be adduced. To continue with the structure: With the commencement of the next segment (see below, p. 179) 4) Candrakīrti rejects Bhāviveka's claim that other-acknowledged inferences have to be adduced, on the ground that the opponent is obligated to first prove his thesis $\left(\mathrm{PsP}_{\mathrm{L}} 19.1-3\right.$; I shall leave $\mathrm{PsP}_{\mathrm{L}}$ 19.3-7 to the side for the moment). Subsequent to this rejection, 5) Candrakīrti concedes and responds to the contention that other-acknowledged inferences have to be adduced by presenting two

${ }_{85}$ Note that at $\mathrm{PsP}_{\mathrm{L}}$ 34.6-10, where Candrakīrti sets forth another otheracknowledged inference, he also takes care to mention the opponent's thesis. 
other-acknowledged inferences. In the course of the extended ensuing discussion he attacks various of Bhāviveka's independent inferences and explains why the propositions and reasons of independent inferences used by the Mādhyamika are doomed to be faulty. He closes the section by defending the use of other-acknowledged inferences.

This is not the place to hypothesize about Candrakīrti's reasons for endorsing other-acknowledged inferences, but they would appear to be more than just the fact that these inferences are immune to the logical faults that would befall any independent inferences used by Mādhyamikas in debates about the ultimate nature of things. One of the reasons that he is not satisfied to close the PsP debate regarding statements of unwanted consequence and independent inferences with his initial response to Bhāviveka's critique (i.e., the response in which he retorts that a statement of unwanted consequence is sufficient to induce a sensible opponent to admit defeat and that an inference will do nothing for a fool), is most certainly to establish, or justify, a type of argumentation that will serve the seventh-century Mādhyamika. Bhāviveka's criticism of Buddhapālita represented in part a reaction to certain developments within the logical-epistemological fold of Buddhism in the first half of the sixth century, i.e., within Dignāga's, the founder of the logical-epistemological school's, circle, that manifested in Bhāviveka's integration of the logical theory and procedure evolved and prescribed there into his own school, which may have appeared to him as one that worked with obsolete tools and was therefore open to attack. Candrakīrti, born into a period in which Dignāga's logic had become authoritative, himself erudite in the intricacies of logical procedure and well-versed in Dignāga's writings on the subject, was aware of the demands of the day and the threat, and his response to the challenge of Bhāviveka (whom he derogatively terms a tārkika throughout the section) must have served the secondary purpose of providing him with a platform from which to address and possibly preempt potential criticism from the logical-epistemological faction itself as regards the Madhyamaka logical procedure. Candrakīrti's partial acquiescence to Bhāviveka's demand for formal inferences in the form of his sanctioning of other-acknowledged inferences was, like Bhāviveka's methodological renovations, a response to his intellectual environment; he was spurred by it to clarify the Madhyamaka argumentative methods - and in this way to bring them up to date -, to distinguish their employment from the prevailing mode of inferential debate, and to justify their 
deviations from Dignāga's rules. ${ }^{86}$ In contrast to Bhāviveka, however, he had enough distance from the developments of the previous century not to be seduced by them to the point that he sacrificed his integrity as a Mādhyamika.

Now to turn to Oetke's interpretation of $\mathrm{PsP}_{\mathrm{L}}$ 18.5-9. Although his translation for the first part of the first sentence is rough and ambiguous, it appears from his summary of the section (cf. Oetke 2003: 117) that he correctly interprets the objector to be conceding that inferences of the type that are accepted by both parties, i.e., independent inferences (svatantrānumāna), cannot be used by a Mādhyamika. The problems arise in regard to the latter half of the sentence, which I translate as

... nevertheless, there must be (bhavitavyam) criticism (codanay $\bar{a})$ of the opponent's thesis for being in contradiction with an inference just from [his] own (= the opponent's) [point of view] (svata evānumāna) by way of a proposition and so forth that are free of the faults of the proposition, reason and example, [each of which is established] only from [his] (= the opponent's) own [point of view].

Oetke translates (Oetke 2003: 116):

... nevertheless, since [the Mādhyamika] reproves [the opponent] of [advocating a tenet which is beset by] a contradiction on account of an inference of his own accord, he must have theses and other [members of an inference] of his own accord which are free from defects [pertaining to] thesis, indicator and example.

Besides overlooking that parapratijñayāh also belongs to the latter half of the sentence, Oetke construes bhavitavyam with pakșädibhih, instead of with ${ }^{\circ}$ codanay $\bar{a}$. In his summary of the segment, Oetke rephrases the statement as "But since even in the present context it is claimed by the Mădhyamika that the counter-thesis is contradicted by some inference he is obliged to present some thesis, inferential indicator and example ..." (Oetke 2003: 117). One wonders where Oetke sees a Mādhyamika

86 I do not intend to suggest that Candrakīrti invented the other-acknowledged inference. Note that Dharmakīrti, presumed to have been a contemporary of Candrakīrti's, cites Sānkhya justification for the use of a reason accepted only by the opponent in Pramāṇavārttika IV.1 (commenting on svadṛșta of PS III.l's remarks on inference-for-others (parārthānumāna). Dharmakīrti asserts that Dignāga's inclusion of the word svadrsțta in PS III.1 was for the sake of eliminating the view that inferences accepted only by the opponent party are admissable. See the translation and comments in Tillemans 2000: 9ff. 
making the blank and vague assertion that the Sānkhya counter-thesis is contradicted by "some" inference, such that the Mādhyamika must now explicitly set forth an inference that contradicts the Sānkhya thesis. Candrakīrti pointed out earlier that Buddhapālita's statement of unwanted consequence is able to show that the Sānkhya thesis of arising from self is contradicted by other convictions of the Sānkhya ( $s v \bar{a}-$ bhyupagamaviruddha; cf. $\mathrm{PsP}_{\mathrm{L}}$ 15.7-8), but nowhere in any of the previous segments is it claimed that the thesis is contradicted by an inference. He does use codanay $\bar{a}$ in a construction at $\operatorname{PsP}_{\mathrm{L}} 15.9$ in the way Oetke would like to construe it here, i.e., independent of a verb (atha svābhyupagamavirodhacodanayāpi paro na nivartate ...), but the reference is to the immediately preceding explicitly stated critique of the Sānkhya thesis intended by Buddhapālita's consequence. The instrumental codanay $\bar{a}$ of this earlier construction further has to be interpreted as "with the censure," a meaning the codanay $\bar{a}$ of the 18.5-9 segment, were it intended to be construed independent of bhavitavyam, would also have; Oetke's "since" forces a causal sense onto the (wrongly construed) codanayā. Now of course Candrakīrti will, a few sentences in the future, claim that the inference implicit in Buddhapāita's statement sublates the Sānkhya thesis, but if this is the "claim" that Oetke is referring to, we will have to assume that Candrakīrti, in using for his ground here an idea that he has not yet introduced, is a sloppy śasstra structurer. I do not think, however, that Oetke considers the reference to be to this later claim. He appears to view the "claim" as one that is being referred to - if out of the blue - for the first time with this segment; but even an atemporal and impersonal interpretation of ${ }^{\circ}$ codanaya, i.e., "with the [Madhyamaka] criticism that there is contradiction ...," is problematic, inasmuch as one expects some sort of previous reference to the criticism or the reasons for it. The context simply does not support the interpretation of an independent codanay $\bar{a}$. The sentence read with $c o-$ danay $\bar{a}$ construed with bhavitavyam yields a symmetrical structure whose thematic progression fits well in the immediate context.

Much more problematic than his interpretation of 'codanay $\bar{a}$ is Oetke's revival of Stcherbatsky's flawed view that sva of svata eva should be taken to refer to the Mādhyamika, a mistake that has been pointed out and corrected by Tillemans. ${ }^{87}$ Oetke's understanding of the meaning of

87 See Tillemans 1992: 318, n. 8. Stcherbatsky, ignoring the segment's first instance of svata eva, translates the second as "in your own opinion." Tillemans' 
svata eva is subtler than Stcherbatsky's, however. Ignoring eva, he translates svata as "of his own accord," and understands it to refer to the fact that the Mādhyamika is being called on to use an inference that relies on categorical propositions, as opposed to hypothetical ones (see Oetke 2003: 129). With the demand for a thesis, etc., "of his own accord," Oetke therefore sees the objector creating "a queer situation" for the Mādhyamika, for he "is invited to argue on the basis of premises which he himself does not consider as true. It is as if he should say: 'A does not originate from itself, because $\mathrm{A}$ is $\mathrm{F}$ like $\mathrm{B}$, but according to my own opinion it is not true that $\mathrm{A}$ is $\mathrm{F}$ and in the final analysis there is no $\mathrm{B}$ - and a fortiori there is no $\mathrm{B}$ which is $\mathrm{F}^{\prime \prime}$ (ibid., p. 118).

Further on in Oetke's article, we learn that Bhāviveka's inference negating that the inner bases arise from self would be an example of the sort of inference being demanded by the objector (Oetke 2003: 129). One's initial reaction to this is to think that Oetke's interpretation would mean that Candrakīti, who has been leading the reader through a carefully crafted semi-dialogue between himself and a hypothetical Bhāviveka, would unexpectedly concoct a slightly sneaky, or maybe just kooky, Bhāviveka, who concedes that a Mādhyamika cannot use independent inferences that are established for both parties (i.e., like the one negating arising from self which he himself uses and which has been referred to by Candrakīrti as an independent inference, i.e., established for both parties), but in the next breath declares that since a Mādhyamika criticizes with inferences he must employ inferences (i.e., like the one negating arising from self which he himself uses, etc.). But such is not meant to be implied by the interpretation. Oetke rather appears to interpret the sentence, if we remain for the moment with the example of Bhāviveka's inference, as implying that Bhāviveka would relinquish the idea of his inference being established for both parties for the idea of it no longer being established for himself. According to Oetke, however, the Mādhyamika's use of inferences that are not established for himself is not a solution, since their categorical nature forces him, as he states, "to argue on the basis of premises which he

translation is commented on in MacDonald 2000: 172, n. 23. Note that although Hopkins translates PsP Tib's rain gi of rai gi rjes su dpag pas as "one's own" and does not translate rañ ñid la of rain ñid la phyogs la sogs pa, he quite clearly understands that an other-acknowledged inference is being called for; he translates ran gi rjes su dpag pas as "through one's own [other-approved] inference" (cf. Hopkins 1983: 480). 
himself does not consider as true." These inference are therefore very problematic for the Mādhyamika, as Oetke's interpretation of the next passage shows. Now, Candrakīrti does indeed very specifically point out the problems of Bhāviveka's inference, but he does so in later passages, not in this and the following segment, and the difficulties he sees involved for the Mādhyamika employing it or any other independent inference are quite different from those Oetke imagines here. He does not argue that Bhāviveka's inference rests on categorical propositions (but is not established for himself), so that it brings him into a "queer situation" in which he will be tied to "wrong existential presuppositions" (Oetke 2003: 129). He instead calls attention to the fact that the subject and the reason of the independent inference, both of which Bhāviveka holds to be established for himself and the opponent in the debate, are in fact not established for both, because Bhāviveka admits the subject and reason conventionally, whereas the opponent accepts them ultimately; the problem is therefore that Bhāviveka's inference is ridden with logical faults (see Yotsuya's brilliant analysis of the section). ${ }^{88}$ The $\mathrm{PsP}_{\mathrm{L}}$ 18.5-9 segment thus is not being used to demand, in place of independent inferences, inferences that rest on categorical propositions so that they too can be rejected. Candrakinti uses the $\mathrm{PsP}_{\mathrm{L}}$ 18.5-9 segment to turn the discussion to the other-acknowledged inferences that are not liable to the existential implications and logical faults that the independent inferences established for both parties are liable to, specifically, to the other-acknowleged inference he claims implicitly exists in Buddhapālita's statement of unwanted consequence.

As mentioned above, that it is Candrakīrti's intention to present such an inference becomes apparent at $\operatorname{PsP}_{\mathrm{L}} 19.8$ with his reiteration of Bhāviveka's demand for an other-acknowledged inference:

The fault that [the Sānkhya thesis is in] contradiction with an inference from [the Sānkhhya's] own [point of view] (svato 'numānavirodhadoṣa) definitely has to be brought out [by way of the Mādhyamika's employment of a proposition, reason and example, all of which are accepted only by the Sānkhya].

But prior to this echo of the demand and his subsequent fulfilling of it, Candrakinti detours, for the sake of spotlighting the hopelessness of the opponent's position. He opens the next segment by claiming that the Mādhyamika is not required to present such an inference because

88 See Yotsuya 1999: chapter 4. 
the onus probandi is on the opponent's side. Since the Sānkhya is unable to present a solid argument proving his position, it is more than clear that his position is untenable; the additional presentation of an otheracknowledged inference for the sake of indicating its untenability would be superfluous.

\section{$\mathrm{PsP}_{\mathrm{M}}\left(\mathrm{cp} . \mathrm{PsP}_{\mathrm{L}}\right.$ 19.1-7), translation and comments:}

ucyate naitad evam | kim kāraṇam | yasmād yo hi yam artham pratijānīte tena svaniścayavad anyeșām niścayotpādanecchayā yayopapattyāā̄e ar-

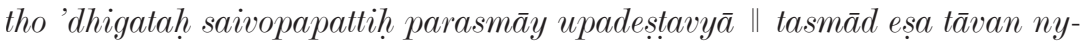
$\bar{a}$ yo yat parenaiva svābhyupagamapratijñātārthasādhanam ${ }^{89}$ upādeyam ।

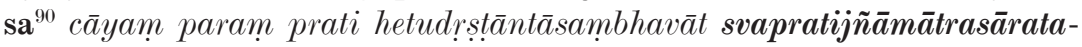
yaiva ${ }^{91}$ kevalam svapratijñātārthasādhanam ${ }^{92}$ upādatta iti nirupapattikapakșābhyupagamāt svātmānam evāyam kevalam visamvvādayan na śaknoti pareṣām niścayam ādhātum iti | idam evāsya spaștataram ${ }^{93}$ dūṣanam

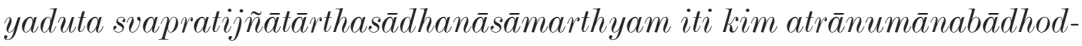
bhāvanaȳ̄ prayojanam ॥

[we would reply to Bhāviveka, who is now faulting Buddhapālita for not having set forth an other-acknowleged inference]: No, this is not the case. [For] what reason? Because [it is] of course $(h i)$ [that disputant] who proposes a [certain] matter (artha) who should, with the desire to bring about certainty (niścaya) in others analogous to [his] own certainty, ${ }^{94}$

89 LVP has emended silently to svābhyupagata ${ }^{\circ}$. All of the manuscripts attest the ma of svābhyupagama ${ }^{\circ}$.

90 Cf. my comments on the $\mathrm{PsP}_{\mathrm{L}}$ and manuscript reading na in MacDonald 2000: 174ff. The *LT attests the sentence in question as commencing with tac cāyam instead of $s a c \bar{a} y a m$, a variant which, like $n a$ of the PsP mss., has to be rejected (see MacDonald 2000: 178, n. 32 for paleographical remarks on the variants).

91 Cf. my comments on the $\mathrm{PsP}_{\mathrm{L}}$ reading in MacDonald 2000: 179, n. 33.

92 Following LVP, I emend the mss.' reading ${ }^{\circ}$ mātram to ${ }^{\circ}$ sādhanam (for the mss.' readings, see MacDonald 2000: 179, n. 34). PsP Tib attests rain gi dam bca' ba'i don gi sgrub par byed pa (= svapratijñärthasādhanam). The change of ${ }^{\circ}$ sādhanam to 'mātram may have occurred when the scribe's eye, attracted by svapratijñ $\bar{a}$ in the previous compound, skipped back to this compound as he was about to write $s \bar{a}$ dhanam (the akșaras $m \bar{a}$ and $s \bar{a}$ are easily confused in the older north Indian scripts).

93 $\mathrm{Ps}_{\mathrm{L}} \mathrm{P}_{\mathrm{L}}$ presents spastatara compounded with the following dussanam. All the mss. but one attest the final anusvāra of spastataram.

${ }_{94}$ Candrakīrti quotes NM 13ab = PS IV.6ab: svaniścayavad anyeșām niścayotpādanechay $\bar{a} /$. For references, cf. MacDonald 2000: 174, n. 25. Candrakīrti cites this famous half-verse of Dignāga's here as part of his refutational strategy, 
teach the other [party] exactly the reasoning (upapatti) by means of which [he] has come to understand this matter. Therefore this, first, is the regular procedure (nyāya): Only the opponent (parena) has to employ a proof of the matter proposed [on the basis of] what [he him]self maintains. But the [opponent] ( $s a$ ) here (ayam) [in the present debate] (= the Sānkhya), on account of - in the view of [his] opponent (= the Mādhyamika) - the impossibility of [valid] reasons and examples, employs (upādatte) a proof of the matter he has proposed only (kevalam) in such a way that [its sound] core (sāra) is nothing but his (sva) mere thesis (pratijñamātra)! ${ }^{95}$ Thus, since he maintains a proposition (pakṣa) lacking justification (nirupapatti), he, fooling (visamvādayan) only himself [with respect to the soundness of his inference], is not able to instill certainty (niścaya) in [his] opponents. ${ }^{96}$ Just this is the [Mādhyamika's] very clear criticism of him, namely, [he] is incapable of proving the matter he has proposed $;{ }^{97}$ under these circumstances (atra), what is the point of bringing out the sublation [of his thesis] by an inference $(a$ numānabā $d h \bar{a}) ?^{98}$

and not because he took as his standard Dignāgean logic. The view put forth in the part of the verse he cites, namely, that one should strive to engender in the opponent the same certainty already attained for oneself, is in fact not specific to Dignāgean logic but is applicable to the context of debate no matter what one's own position on logic and argumentation is.

${ }_{95}$ The sentence is interesting from a stylistic point of view because it is an example of one of Candrakīrti's trademark methods for neutralizing an opponent's critique. The more usual version of this method involves Candrakīrti criticizing the opponent for having exactly the fault he has accused Candrakīrti of; he turns the critique back on the critiquer, sometimes with an even more devastating element added to it. Here the situation is indirect: he turns Bhāviveka's critique of Buddhapālita's prasanga statement, i.e., that it lacks a reason and example, on the opponent Sānkkhya; he thus indirectly turns it on Bhāviveka by turning it on the Sāṅkhya. Candrakīrti here charges the opponent, as Bhāviveka does Buddhapālita and other opponents in the PP, with arguing for his position with a "mere thesis" (pratijñāmātra). He also takes Bhāviveka's criticism of Buddhapālita one step further: the Sānkhya, unlike Buddhapālita who, according to Bhāviveka, has not utilized a reason and example and must merely add them, utilizes reasons and examples which fall apart under the Mādhyamika's critical eye; logically sound reasons and examples, given the Sānkhya's indefensible position of arising from self, are impossible for the Sānkhya.

96 PsP Tib: gźan la for pareșām (i.e., Tib without a plural marker)

${ }_{97}$ PsP 'Tib: ran gi dam bca' ba'i don gyi sgrub par byed pa for svapratijñātārtha$\operatorname{sa} d h a n \bar{a}^{\circ}$.

98 A proposition (paksa) that is liable to sublation by an inference is the fifth of the five pakșābhāsas enumerated in NM; cf. Tucci 1930: 7f.; Katsura 1977: 113; Preisendanz 1994: 319ff. (= n. 88). 
With the above I refine certain aspects of my earlier translation of the passage (cp. MacDonald 2000: 179). In particular, I have changed the translation of param prati from "against [his] opponent" to "in the view of [his] opponent" because "against" suggests that the reasons and examples are aimed at disproving an opponent's thesis; here they are simply being used to prove a thesis. The idea behind "in the view of" is that the Mādhyamika's critical eye discerns the logical flaws of and/or the inapplicability of any reason and example the Sānkhya might set forth. ${ }^{100}$ I also modify my earlier translation of sāra from "main constituent" to "[sound] core" for the sake of stressing the qualitative as opposed to quantitative judgement being made here. I further revise my previous translation for svātmānam eva ... visamvāadayan from "disagreeing with no one but himself" to the pejorative and much more appropriate "fooling only himself."

The emendation of $\mathrm{PsP}_{\mathrm{L}}$ 19.3's na cāyam to sa cāyam has unquestionably improved the text. I am now of the opinion that the author of the PsP "commentary," the *Lakṣaṇațīa (*LṬ), which attests the "cita-

99 Cf. Monier-Williams s.v. prati: mām prati "according to me, in my opinion,
... to me."
100 It is interesting to note that Peter della Santina records that bSod-nams Sen-ge asserts that the reason is "as unproven as the proposition" and that the proposition is "not supported by any example or precedent met with in common experience" (della Santina 1986: 143f.). See also Hopkins' comments on the Sānkhya proof (Hopkins 1983: 479f.).

101 I had in fact revised my translation to read "deceiving no one but himself" even before the WZKS 2000 article was published. One of the main reasons I took up the discussion with Oetke in the autumn of 1999 was my dissatisfaction with the translation "disagreeing" for visamvādayan (especially in construction with the accusative svātmānam). When I mentioned my revision to Oetke, however, he insisted that it was wrong, which unfortunately led me to revert to "disagreeing with no one but himself" for the publication. Still unhappy with the translation, I nonetheless saw some support for it given that the Sānkhya could possibly be seen as thinking that his proof demonstrates his disagreement with the Mādhyamika view that things do not arise from self - but since the Mādhyamika does not accept the proof, the Sānkhya would be left "disagreeing with no one but himself." Note that Hopkins has correctly interpreted PsP Tib's bdag ñid kho na la slu bar byed $p a(s)$ as "deceives just himself," but has wrongly taken the agent of the act of deception to be the argument itself, which of course the masculine ayam as PsP Skt's agent of the action prohibits (idam would be required for a reference to sādhanam) (cf. Hopkins 1983: 481). Seyfort Ruegg does not explain why he interprets svātmānam evāyam kevalam visamveadayan to mean "and being in conflict in respect to [the term] svātman '[from] itself" (2002: 32). 
tion" tac cāyam for PsP's sa cāyam, did rely on a manuscript of the PsP that read sa cāyam; the sa cāyam that he copied into the *LT must have degenerated independently to tac câyam due to scribal error and interference (the other scribal errors in the *LT inform of its being a copied manuscript). Two sentences previous to tac cāyam the *LT reads: tasmāt parenaiva svapratijñ̄āârthasādhanam hetudrștāntādibhir upādeyam nāsmābhih. ${ }^{102}$ The next sentence, which introduces the "citation" tac cāyam, reads: atha so pi pare vinā hetvādibhih param pratipādayisyatīty $\bar{a} h a$ । tac cāyam ityādi. The statement so pi pare vinā hetvādibhih param pratipādayisyati clearly represents the *LT author's paraphrase of PsP's sa (according to *LṬ’s citation: tac) cāyam param prati hetudrṣtāntāsambhavāt ... svapratijñātārthasādhanam upādatte. I had earlier accepted the *LT reading pare of the paraphrase as a locative singular form ("this one, without reasons and examples in regard to/for [his] opponent, will instruct [his] opponent") and suggested that the preceding sa might even represent the preserved original reading for the PsP. ${ }^{103}$ I now believe, thanks to the comments of L. Schmithausen and K. Preisendanz, that pare is more likely a corruption of paro, and that paro is intended as a gloss of $s a$ of the same paraphrase. The *LT author's citation and gloss of $s a$, then, would confirm that he read $s a$ in the PsP ms. available to him, and that the $\mathrm{PsP}_{\mathrm{M}} s a$ which was until now a conjecture can be accepted as the original reading. This "hidden jewel" of the *LT paraphrase (but not of *LṬ's actual "citation" of the text, i.e., tac cāyam, the sa of which has degenerated to tac!) attests to the testimonial importance of such commentaries.

Oetke's main point of difference with my interpretation of the emended version of $\mathrm{PsP}_{\mathrm{L}}$ 19.3-7 concerns the referent of $s a$ cayam. He claims that it is a Mādhyamika; I claim that it is the Sānkhya. That the reference is to the Sānkhya becomes clear with language use considerations. Readers of the passage familiar with the meaning and use of pronouns will understand that $s a$ is being used anaphorically in the meaning of "the aforementioned," and will refer it back to a noun stated shortly before. The two possibilities in this context are nyāya, the "regular procedure," and para (parena), the "opponent," of the previous sentence. nyāya has to be excluded in view of the fact that the verb upāatte requires a person as subject. para, which perhaps should be understood generally as any opponent who maintains a thesis, must be the referent.

102 See Yonezawa 1999: 1023.

103 See MacDonald 2000: 178, n. 32. 
The use of the word "opponent" in this previous sentence alludes to the fact that the person meant is any opponent of the Mādhyamika's who maintains a thesis. A specification of the opponent is made by means of ayam of $s a$ cayam - for otherwise $s a$ would have been sufficient through the fact that with it there is reference, again by way of the semantic feature of deixis ("pointing") inherent in all demonstrative pronouns, to an entity that is near or present. ayam thus particularizes $s a$ as the opponent being referred to here, that is, the specific opponent with whom the debate is being carried out, namely, the Sānkhya.

Candrakīrti thus commences the sentence beginning with sa cāyam by declaring that the Sānkhya tries to prove his position with reasons and examples that are, from the point of view of the Mādhyamika, just bogus supports for the thesis he aims to prove. Since the reasons and examples in his proof are faulty, the Sānkhya ends up proving his proposition by way of an argument that has nothing but (eva) his mere (mātra) claim, i.e., nothing but his own thesis (svapratijña), as its "[sound] core" (sāra), as the sound element in it that cannot be invalidated, as the argument's solid, sturdy heartwood. Clearly, Candrakīrti is using the word sâra ironically. Without a reason and example to support it, the thesis is not at all sturdy; it is actually extremely shaky, indeed on the verge of a total collapse. The accumulation of the elements mätra, eva and kevalam in the Sanskrit sentence indicates strong emphasis: mātra sets the limit, eva underscores this limit as definite ("nothing but"), and kevalam may be adding a nuance of the deficiency and pitifulness of a such an argument. While the Sānkhya fools himself into believing that his miserable argument is incontrovertible proof of his position, his Mādhyamika opponent sees that it confirms nothing, and cannot be converted.

We might even be justified in reading this passage as an interpretation of Buddhapālita's intention: His statement of unwanted consequence was merely intended to show, or at least allude to, the inability of the Sānkhya's argument to prove (sādhanāsamarthya) his own thesis.

Oetke, as stated, holds that the subject of the passage is a Mādhyamika. Thus according to him, in the main sentence commencing with sa cāyam, Candrakīrti describes the nature of the inference used by the Mādhyamika who follows the recommendation of $18.5-9$ and the pickle he will end up in (Oetke vascillates between terming the call for the inference a "demand," a "recommendation," and "advice"). Oetke translates (Oetke 2003: 124): 
But this one (i.e. the Mādhyamika who acts according to the postulate that has been advocated in the preceding objection) employs against [the] other [interlocutor] (i.e. his opponent) only a means of proving the proposition asserted by himself in such a way that its essence is only an assertion [and not as something which is accepted by him] because [for him] indicators and examples are not possible [as entities which are acknowledged as existing by him]; therefore he brings only himself into inconsistency [with himself] because he accepts a thesis as something which lacks [appropriate] support and cannot instill conviction in other [persons, who do not by themselves believe his thesis, in particular his opponents].

In determining the Mādhyamika to be the subject of the passage, Oetke must have turned a blind eye to the fact that his mode of dealing with pronouns here contradicts his postulate that the referents of demonstrative pronouns "can be found out by a potential hearer or reader with sufficient certainty and without requiring an unreasonable amount of effort" (Oetke 2003: 127). Oetke also overlooks that two pronouns, $s a$ and ayam, have to be taken into consideration. He does not seek out a referent for $s a$ at all; he ignores it (somewhat questionable procedure for a scholar who, alluding to his analysis of $\mathrm{PsP}_{\mathrm{L}}$ 19.3-7, states, "There are cases in which it is apposite to account for each individual word including the most minute particles" [ibid., p. 130]). Oetke instead focuses on ayam. He does not seek a referent for it in nyāya or parena or any other noun of the segment, but rather decides that Candrakīrti intends it in a more general way to refer to any Mādhyamika who might follow the $\mathrm{PsP}_{\mathrm{L}}$ 18.7-8 recommendation and set forth an independent inference. In Oetke's words: “... ayam in sa cāyam param prati is employed in order to refer (in a general manner) to a(ny) person who follows the advice that had been formulated in the preceding objection ..." (ibid., p. 124-125). I think that most readers of the passage will agree that this as an extremely forced interpretation of ayam, and one that is neither required nor supported by the context.

Even if Oetke had taken $s a$ into consideration and insisted that its referent has to be the Mādhyamika because he was mentioned at $\mathrm{PsP}_{\mathrm{L}}$ 18.5, the argument would have to be rejected, because the form there is $m \bar{a}$ dhyamikānam, and a plural form can hardly be the referent of singular sa.

To return to my interpretation: $s a$ refers back to para of $\mathrm{Ps}_{\mathrm{s}} \mathrm{P}_{\mathrm{L}} 19.3$ and ayam specifies that the opponent is the Sānkhya. para of 19.4's param prati, then, has to be understood as the Sānkhya's opponent, i.e., the 
Mādhyamika. ayam of 19.5 is again clearly the Sānkhya, and pareșàm of 19.6 his opponents, the Mādhyamikas (cf. the genitive plural of 18.5). asya of the following sentence idam evāsya spaștataram dūsanam yaduta svapratijñātârthasādhanāsamarthyam is naturally once more the Sānkhya. Oetke points out that the referent of asya could be sādhana of 19.4 (he translates "of him/it" [Oetke 2003: 127]), a suggestion that cannot be dismissed. Oetke's minimizing of the problem involved when the referent of asya is taken to be the Sānkhya even though the referent of the previous two ayams is, in his opinion, the Mādhyamika is, however, unacceptable. asya needs a referent, and the referent of singular asya definitely cannot be plural pareșām, as Oetke would have it; Oetke anyway understands pareșām to be intended in the more general sense of "other [persons, who do not by themselves believe his thesis, in particular his opponents]" (ibid., p. 124).

Given that the referent of $s a$ has to be the Sānkhya, and that otheracknowledged inferences, not (according to Oetke's interpretation) inferences relying on categorical propositions, are called for with $\mathrm{PsP}_{\mathrm{L}}$ 18.5-9, I see little point in critiquing Oetke's explanation of the rest of the segment in any detail. Let it merely be said that his strained explanation of the compound svapratijñamatrasāratayā, especially of the word sāra (see Oetke 2003: 125f.) is completely unconvincing, and that his mode of dealing with the text, i.e., his dropping of sva from the compound (sva is attested in the palm-leaf manuscript and all fourteen paper manuscripts) because it does not suit his purposes, is highly suspect. There is one point made by Oetke, however, that does need to be addressed. In the course of setting forth his objections to my earlier conclusion that the Sānkhya is referred to with sa cāyam, he argues that if the subject of svapratijñatārthasādhanam upādatte ("employs a proof of the matter he has proposed"; $\mathrm{PsP}_{\mathrm{L}}$ 19.4-5) really would be the Sānkhya, then one would expect to find some mention of or allusion to the Sānkhya having offered a proof of his thesis somewhere in the preceding text passage (ibid., p. 120). I do not consider it a problem that such is not to be found in the preceding passage. Some Sānikhya proof(s) for the position that things arise from themselves, or for a corresponding position, such as that of satkāryavāda, would certainly have been known to the Mādhyamikas; note that Sānkhyakārikā 9 sets forth five reasons in support of satkāryavāda. ${ }^{104}$ It is possible, even though Can-

104 Sāṅkhyakārikā 9: asadakaran̄ād upādānagrahan̄āt sarvasambhavābhāvāt / śaktasya śakyakaraṇāt kāranabhāvāc ca sat kāryam //. See YD p. 109-125 for a de- 
drakīrti appears to be making reference to one of the words of a thesis at (emended) $\mathrm{PsP}_{\mathrm{L}}$ 15.4-5 when he states parah svata utpattim abhyupagacchan vidyamānasya punarutpāde prayojanam prcchyate I svata iti vidyamānam hetutvena bravissi tad eva cotpadyata iti, that the thesis Candrakinti refers to in the 19.3-7 segment was not formulated exactly as bhāva h svata utpadyante, but even if this was the case, one expects that the reason(s) and example(s) of the inference were proving something similar. It is perhaps worth mentioning in this respect that in the first chapter of his PP Bhāviveka presents a five-membered Sānkhya inference which proves that the cause of the "inner distinctions" (nain gi bye brag rnams) are the three gunas. ${ }^{105}$

Oetke praises his interpretation of the emended version of $\mathrm{PsP}_{\mathrm{L}}$ 19.3-7 as having major consequences for the understanding of a larger section of the PsP (Oetke 2003: 130) and as having "potential relevance for the understanding of fundamental features of Candrakīrti's philosophy and methodology" (ibid.). I am afraid that the discoveries he makes for the section on the basis of his interpretation, like the Mādhyamika(s) he fabricates for 19.3's ayam, are more his own invention than a revealing of Candrakīrti's views. Summarized, his ideas are as follows. Because he understands 19.3-7 as elucidating why the inferences recommended in the 18.5-9 segment are problematic, and since Candrakīrti claims at 20.1 that Buddhapālita did bring out the Sānkhya thesis' contradiction with an inference, Oetke infers that there must be a difference between the inference recommended in the 18.5-9 segment and the inference referred to at 20.1 and detailed in the subsequent passages. The difference, he concludes, is that the recommended inference relies on categorical propositions, which lead the Mādhyamika into inconsistency because they presuppose that he accepts them when he does not, whereas the inference Candrakīrti claims is implicit in Buddhapālita's consequence relies merely on conditional propositions, which do not implicate the Mādhyamika in wrong existential presuppositions. The former, unacceptable inference is of the form "A is S, because A is $\mathrm{H}$, like B," whereas the latter would be, in its explicit form:

fense of satkāryavāda and an explication of the five reasons set forth in Sānkhyakārikā 9 for the pre-existence of the effect in the cause.

${ }_{105}$ See PP D 52a6-52bl and Ames 1993: 231f. Ames notes that Avalokitavrata glosses "internal distinctions" (naí gi bye brag rnams; Ames suggests *ādhyātmikā bhed $\bar{a} h)$ as "the inner a yatanas, the eye and so on, which are distinguished by mutually different characteristics" (1993: 249, n. 176). 
"There is no A which is $\mathrm{S}^{*}$, because if there were some A which is $\mathrm{S}^{*}$ it would be $\mathrm{H}$, and if there were some $A$ which is $\mathrm{H}$, it would be (I, J, K ... and therefore) not $* S "$ (Oetke 2003: 129). Oetke admits that he finds the passage in which Candrakīrti explains the latter inference ${ }^{106}$ "obscure with respect to certain details" (ibid., p. 128) and notes that this inference based on conditional propositions "does not fit in the framework of the classical anumana-doctrine" (ibid., p. 129).

According to my interpretation of the section, and at the risk of repeating myself, it is an other-acknowledged inference, i.e., an inference just from the opponent's point of view (svata evānumāna), that is demanded in the $\operatorname{PsP}_{\mathrm{L}}$ 18.5-9 segment. As stated earlier, Candrakīrti refers again at $\mathrm{PsP}_{\mathrm{L}} 20.1$ to exactly this sort of inference, and with the next sentence begins to show just how such an inference can be drawn out of Buddhapālita's statement. The five-membered other-acknowledged inference he derives from Buddhapālita's statement has exactly the same form as any other classical five-membered inference; it differs only in being accepted solely by the opponent party. Subsequent to deriving this inference, Candrakīrti presents another other-acknowledged inference, this time of the Dignaggean three-membered type. Its form is precisely "A is $\mathrm{S}$, because $\mathrm{A}$ is $\mathrm{H}$, like $\mathrm{B}$," the form Oetke considers Candrakinti to reject. It deviates from the three-membered inferences accepted by Dignāga only in being accepted exclusively by the opponent. As explained earlier, it is this acceptance solely by the opponent that is the distinguishing feature of Candrakīrti's inferences.

I realize that I have not addressed everything that could be discussed regarding Oetke's interpretation of this section of the PsP, but I believe that some of the most basic problems have been touched upon. One would hope that the far more satisfactory reading that my interpretation of the section provides would, in the demonstration of the careful consideration that has gone into it, give Oetke pause for thought and suggest to him that there may well be more scholars in the field of Indology than he would like to admit who are aware of and work using viable and effective methodologies. Speaking generally, it is extraordinarily simplistic to assume that critical reflection has not taken place on the part of others just because one does not reach the same conclusions or because this reflection is not documented in detail. Nevertheless, I am certain that Oetke's meticulous description of and discussion

106 See $\mathrm{PsP}_{\mathrm{L}}$ 20.1-21.6. 
regarding the optimality-principles will prove valuable to students and scholars who have not yet learned or are in the process of learning to work critically.

\section{Appendix: Text-Critical Comments}

1) PsP Sanskrit atiprasangadoșāt (cf. $\mathrm{PsP}_{\mathrm{L}}$ 14.1-2) vs. BP 'Tib skye ba thug pa med par 'gyur ba'i phyir

The second fault stated by Buddhapālita is presented in BP Tib as skye ba thug pa med par 'gyur ba'i phyir $\left(\mathrm{BP}_{\mathrm{ed}} 10.13-14\right.$; LVP reconstructs as janmānavasthānāt $\left[\mathrm{Ps}_{\mathrm{L}}, 14, \mathrm{n} .1\right]$ "because there would be an infinite succession of arising"). PsP Skt, in contrast, reads atiprasañgadoșāt. A comparison of each of the PsP Tib quotations in the first chapter of the PsP with both their PsP Skt versions and their versions in the Tibetan source translations has allowed me to conclude that the PsP Tib translators did not translate the citations they encountered in PsP Skt, but rather copied the Tibetan of the premade translations of the source texts directly into PsP Tib, occasionally making minor adjustments to the text of the premade translation (see above, p. 163). I am therefore of the opinion that the PsP Tib translators "pasted" in the BP Tib quotation - which they have taken over from either BP or PP (the citation is identical in both) - and introduced certain changes, one of them being the change from skye ba thug pa med par 'gyur ba'i phyir to shin tu thal bar 'gyur ba'i phyir, a change that permits PsP Tib to better reflect PsP Skt's atiprasangadoṣāt (doşa has not been translated). Note that Candrakīrti makes reference to anavasth $\bar{a}$ in his defence of this statement of Buddhapālita's (cf. $\mathrm{PsP}_{\mathrm{L}}$ 15.6), which might suggest that the reading in BP Skt was *janmānavasthatvāt. He also makes reference to anistha ('na[vasthā] cappy anisteti of $\mathrm{PsP}_{\mathrm{L}} 15.7$ must be emended to na cappy anistheti), which could alternatively suggest that the reading in BP was *janmanisțatvāt. The lack of a corresponding abstract form and the 'gyur ba in BP Tib, on the other hand, could indicate that *janmānisthapatteh comes closer to the original Sanskrit compound.

Whatever the original reading, it would appear that Candrakīrti, as in a number of other cases in the first chapter, is responsible for the change in wording. Of course, it not impossible that Jñanagarbha and Klu'i rgyal mtshan, the translators of $\mathrm{BP}$ and $\mathrm{PP}$, also read atiprasaingadosăt and decided to spell out the absurdity in their translation; one would have to be better informed about their translation techniques to know 
if they took such liberties with the text. Buddhapālita's explanation atha sann api jāyeta na kadācin na jāyeta, however, would seem to nicely explain *janmānișthā (patteh). It is also possible, though I think less likely, that BP attested *anisthāprasangadosāt and that this had become corrupted by the time Candrakīrti read the text to atiprasangadosāt. It is, however, difficult to imagine why the BP translators would have translated the former as skye ba thug pa med par 'gyur ba'i phyir. Later on in the first chapter of the PsP, PsP Skt's "fault of a succession without end" (anișthādoṣa) is translated with thug pa med pa'i skyon (LVP has wrongly emended to anavasthādoșa $\left[\mathrm{Ps}_{\mathrm{S}} \mathrm{P}_{\mathrm{L}}\right.$ 61.8-9]). See also $\mathrm{PsP}_{\mathrm{L}} 210.16$ where $\mathrm{PsP}$ Tib translates aniṣthādoṣaprasangāt (LVP reads aniștadoṣaprasañgāt; mss. P and D read aniṣthāasosaprasañgāt) as thug pa med par thal ba'i phyir, and CŚ'T ${ }_{\text {ed }}^{228.16}$ (Tib 229.25-26) where anișthāprasangāt (see CŚT ed $^{228, n .13}$ where the text's reading aniștaprasangāt is corrected to anișthāprasangāt) is translated as thug pa med par thal ba'i phyir.

2) $c a$ of paroktadoṣāparihārāc ca and of prasañgavākyatvāc ca (cf. $\mathrm{PsP}_{\mathrm{L}}$ 14.4-15.1)

None of the $\mathrm{Ps} \mathrm{P}$ mss. attest a ca after paroktadoșāparihārāt, but $\mathrm{Ps} \mathrm{P}$ Tib, PP (moreso PP P than D), and PPT appear to confirm that it was included in the original Skt of PP and PsP. On the reinterpretation of cca akṣaras, see n. 10.

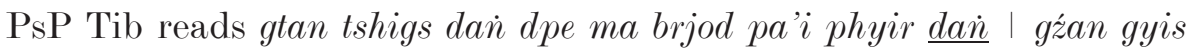
smras pa'i ñes pa ma bsal ba'i phyir ro \| thal bar 'gyur ba'i tshig yin pa'i phyir ... . Although the Peking and Derge translations of this section of PP diverge, both also appear to support inclusion of $c a$ (as can be seen further on in the PsP, however, PsP Tib often adds dans where PsP Skt - correctly - does not attest cas; PP Derge could also be taken to reflect a list of three reasons connected by a single final $c a$ ). The corresponding section of PP P reads: gtan tshigs dan dpe ma brjod pa'i phyir $\underline{\text { dañ }}$ | gźan gyis smras pa'i ñes pa ma bsal ba'i phyir ro $\|$ (= PsP Tib) glags yod pa'i tshig yin pa'i phyir te ... (58b8-59a1). PP D reads: gtan

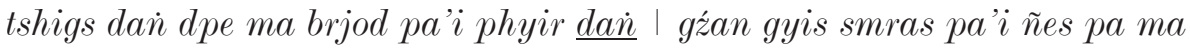

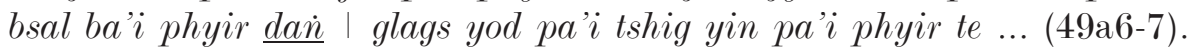
Given that Peking tends to preserve original readings, I consider PP P to better reflect Bhāviveka's original Sanskrit (against Yotsuya 1999: 76). It is doubtful that PP D's second dain reflects a consciously chosen translation of $c a$ of prasangavākyatvāc $c a$ as found in the $\mathrm{PP}$ citation in PsP Skt, for such cas are normally translated by yain; I expect that 
PP D originally read as PP P and that dain was, in the absence of an unambiguous ( $\mathrm{I}$ admit that te could have intended $c a$ ) equivalent for $c a$ that would herald the stating of a third reason, added as an editorial improvement or clarification.

Most helpful is the fact that Avalokitavrata comments on the word $c a$ (yain) occurring after prasangavākyatvāt; this confirms that this $c a$ as found in PsP Skt (but lacking in PsP Tib and PP Tib) also stood in PP Skt. Note too that PPṬ's quotation of Bhāviveka's critique also contains this yain, and that the first two criticisms, as in PsP Tib and PP $\mathrm{P}$, are presented as a separate unit (gtan tshigs dan dpe ma brjod pa' $i$ phyir dan் I gźan gyis smras pa'i ñes pa ma bsal ba'i phyir ro $\|$ glags yod pa'i tshig yin pa'i yain phyir te I skabs kyi don las bzlog pas ... (PPT D 73b3-4; P 85b8-86a1). Avalokitavrata states that this $c a$ indicates that a third fault is being stated. That he deems it necessary to comment on ca after prasangavākyatvāt as indicating yet another criticism of Buddhapalita's statement probably shows that he wanted to point out that the three ablatives indicate three reasons of equal weight or status. Thus, even though this $c a$ is a mere sentence connector (i.e., with it a new sentence starts) that does not connect the reason itself with the two previous reasons, he wanted to indicate that the reason in the sentence it introduces is on a par with the two others. PPṬ: gźan yan de ji ltar rigs pa ma yin źe na I glags yod pa'i tshig yin pa’i yan phyir te I gnas brtan buddha pā li tas bśad pa (D: rnam par bśad pa) de ni rgol ba gźan gyi klan ka'i glags yod pa'i tshig yin pa'i phyir yan rigs pa ma yin no ॥ yan żes bya ba’i sgra ni gtan tshigs dan dpe ma brjod pa'i phyir dan gźan gyis smras pa'i ñes pa ma bsal ba'i phyir rigs pa ma yin par (D: pa) 'ba' źig tu ma zad kyi I de ni glags yod pa'i tshig yin pa'i phyir yan rigs pa ma yin no źes bya bar sbyar ro ॥ (D 74a2-3; P 86a7-86b1; quoted in Seyfort Ruegg 1981: 64, n. 203). Avalokitavrata's commentary is translated in Hopkins 1983: 462-466. Hopkins notes that Tson kha pa points out that the translations of the beginning of the third criticism vary, "indicating that he favors glags yod pa'i tshig yin pa'i yain phyir te as it is in the edition of Bhāvaviveka he had before him and in Avalokitavrata in the sense of meaning, '[Buddhapālita's interpretation] is also unsuitable because of having words that afford an opportunity [to an opponent to expose contradiction within his own system]"' (1983: 819, n. 375$)$.

The emended PsP Skt would thus, if we disregard for the moment the difference between the translations thal bar 'gyur ba'i tshig and glags yod pa'i tshig, appear to mirror the structure of the original PP Skt. 
Ames appears to translate this part of the PP following Peking and therefore adds "also" in square brackets: "That is not [logically] possible, because no reason and example are given and because faults stated by the opponent are not answered. [Also,] because it is a prasanga-argument, a [property] to be proved ..." (1993: 222). Yotsuya, on the other hand, choses to translate following Derge: "This is incorrect, because neither a logical reason (gtan tshigs, hetu) nor a logical example (dpe, drsțtanta) has been presented. Nor has the fault (nes pa, doṣa) pointed out by [your] opponent (= the Sāmkhya) been eliminated. Furthermore [it is unacceptable] because it is a statement which is open to an objection. Since by the reversal of the matter under discussion ..." (1999: 76).

3) PsP Skt prasangavākya (cf. $\mathrm{PsP}_{\mathrm{L}}$ 15.1) vs. PP Tib glags yod pa'i tshig (*sāvakīásavacana)

William Ames states that the appearance of glags yod pa'i tshig (*sāvakāsavacana) in the PP instead of thal bar 'gyur ba'i tshig (prasangavākya) "does not necessarily mean that the translators had a different Sanskrit text. They may have translated prasainga-vākya in this way because of the context and because of Avalokitavrata's subcommentary. Avalokitavrata glosses glags yod pa'i tshig as rgol ba gźan gyi klan ka'i glags yod pa'i tshig, 'a statement affording an opportunity for censure by an opponent (Ava P 86a-8, D 74a-2)'” (1993: 244, n. 102). I am inclined, against this, to think that the PP translators did read sāvakāsavacana in their ms(s). and thus translated literally, and that it was Candrakinti who re-worded sāvakāśavacana here and on other occasions as prasangavākya. His usage of sāvakāsavacana in the later question kuto nu khalu ... ācāryabuddhapālitasya sāvakāśavacanābhidhāyitvam (see $\mathrm{PsP}_{\mathrm{L}}$ 24.1-2) is otherwise unexpected and unusual, especially because it is precisely with this sentence that he directly refers to the third fault mentioned by Bhāviveka. Note that when Candrakīrti finishes his argumentation against specific faults and then refers back to them, he tends to formulate his rejection of the fault as a question, e.g., tat kim ucyate tad ayuktam hetudrștāntānabhidhānād iti; kutah siddhasādhanapakșadoșāsañka kuto vā hetor viruddhārthatāśanketi; kuto nu khalu ... $\bar{a}$ cāryabuddhapālitasya sāvakāsavacanābhidhāyitvam; the aberrant translation de'i phyir kho bo cag la grub pa'i mtha' dan 'gal ba ga la yod for tataś ca siddhāntavirodhāsambhavah in the reasoning concluded by kuto nu khalu ... can probably be explained as the result of the Tibetan translators having noticed this tendency and having decided to present this 
conclusion as well as a question. I think it more likely that with kuto nu khalu ... àcāryabuddhapālitasya sāvakāśavacanābhidhāyitvam Candrakīrti intentionally foregoes his earlier re-wording and employs exactly Bhāviveka's terminology for the sake of having used it at least once and for the stylistic punch it delivers.

4) PsP Skt parasmād utpannā bhāvā janmasāphalyāj janmanirodhāc ceti (cf. $\mathrm{PsP}_{\mathrm{L}}$ 15.1-2) vs. PP Tib and $\mathrm{Ps} \mathrm{P}$ Tib dnos po rnams gźan las skye

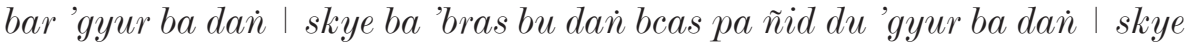
ba thug pa yod par 'gyur ba'i phyir

PsP Tib mirrors PP Tib in separating out and listing the reversed sādhya and sādhanas that, according to Bhāviveka, are implied in Buddhapālita's original statement instead of, as PsP Skt does, merely presenting the unitary counterpart to Buddhapālita's statement inter-

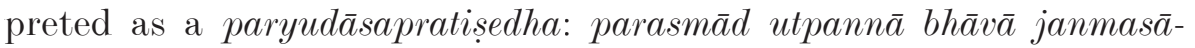
phalyāj janmanirodhāc ceti: ... dinos po rnams gźan las skye bar 'gyur ba

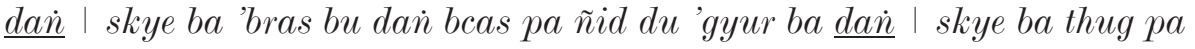
yod par 'gyur ba'i phyir. In two other passages in which Bhāviveka criticizes Buddhapālita's prasangas in a similar way, namely, his criticisms of Buddhapālita's prasanga refuting arising from other and that refuting arising from no cause, $\mathrm{PsP}_{\mathrm{s}} \mathrm{Tib}$ and PP Tib likewise only provide a serial layout of the reversed limbs of the prasangas without construing them as a unified statement: for the former prasanga, the reversal is presented in $\mathrm{Ps} \mathrm{P}$ Skt as svata ubhayato 'hetuto votpadyante bhāvāh kutaścit kasyacid utpatteh, but appears in PsP Tib as: des na de la thal bar 'gyur ba'i nag yin pa'i phyir bsgrub par bya ba dañ sgrub par byed pa bzlog par byas na I dinos po rnams bdag gam gñis sam rgyu med

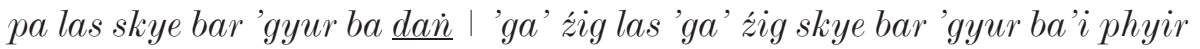
... (cp. PP D 50a6; P 60a6-8); for the latter prasanga, PsP Skt presents the reversal as hetuta utpadyante bhāvāh kadācit kutaścit kasyacid utpatter ārambhasāphalyāc ca, but PsP Tib reads: gal te bsgrub par bya ba dain sgrub par byed pa bzlog pa gsal ba ñag gi don du mn்on par 'dod na I de'i

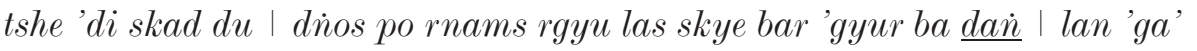
kha cig las kha cig skye bar 'gyur ba dain I rtsom pa 'bras bu dain bcas pa nid du 'gyur ba'i phyir ro (cp. PP D 53a5-6; P 64a5-7). The same mode of presentation is found in the corresponding sections of the PPT (like the PP, translated by Jñānagarbha and Klu'i rgyal mtshan). Such passages show quite clearly that the PsP translators had at their disposal a translation of the PP to which they referred for such quotations. 


\section{Bibliography and Abbreviations}

Ames 1993

BHSD

$\mathrm{BP}$

$\mathrm{BP}_{\text {ed }}$

Chakravarti 1975

CŚ

CŚ́Ṭed

D

de Jong 1978

de Jong 1981

della Santina 1986

Frauwallner 1984

Hopkins 1983

Huntington 2003

Kajiyama 1963

Katsura 1977, 1979

Larson -

Bhattacharya 1987

*LT

LVP

MMK

MacDonald 2000
William L. Ames, Bhāvaviveka's Prajñāpradīpa. A Translation of Chapter One: "Examination of Causal Conditions" (Pratyaya). JIP 21 (1993) 209-259.

Franklin Edgerton, Buddhist Hybrid Sanskrit Dictionary. New Haven 1953.

Buddhapālita Madhyamakavrtti

Buddhapālita Madhyamakavṛtti edition. See Saito 1984.

P. Chakravarti, Origin and Development of the Sāmkhya System of Thought. New Delhi: Munshiram Manoharlal ${ }^{2} 1975$.

Catuhśataka.

Catuḥśatakațīkā edition. In: Sanskrit Fragments and Tibetan Translation of Candrakīrti's Bodhisattvayogācāracatuhśatakațikā. Ed. K. Suzuki. Tokyo: The Sankibo Press, 1996.

Derge

J.W. de Jong, Textcritical Notes on the Prasannapadā. IIJ 20 (1978) 25-59, 217-252.

Id., Review of Sprung 1979. IIJ 23 (1981) 227-230.

Peter della Santina, Madhyamaka Schools in India. Delhi: Motilal Banarsidass, 1986.

Erich Frauwallner, History of Indian Philosophy. Transl. V.M. Bedekar. Salzburg - Delhi 1973. Reprint Delhi: Motilal Barnasidass, 1984.

Jeffrey Hopkins, Meditation on Emptiness. London: Wisdom Publications, 1983.

C.W. Huntington, Jr., Was Candrakīrti a Prāsañgika? In: G. Dreyfuss - S. McClintock (ed.), The Svātantrika-Prāsangika Distinction. Boston: Wisdom Publications, 2003, p. 67-91.

Y. Kajiyama, Bhāvaviveka's Prajñāpradīpaḥ (1. Kapitel). WZKSO 7 (1963) 37-62.

S. Katsura, A Study of Nyāyamukha. Hiroshima Daigaku Bungakubu Kiyō 37 (1977) 106-127 \& 39 (1979) 63-83.

G.J. Larson - R.S. Bhattacharya (ed.), Sāṃkhya: A Dualist Tradition in Indian Philosophy. Encyclopedia of Indian Philosophies, Volume 4. New Delhi: Motilal Banarsidass, 1987.

*Lakșaṇațikā. See Yonezawa 1999.

de La Vallée Poussin

Mūlamadhyamakakārikā(s). See Pss.

Anne MacDonald, The Prasannapadā: More Manuscripts from Nepal. WZKS 44 (2000) 165-181. 
NM

Oetke 2003

$\mathrm{P}$

PP

PPT

Preisendanz 1994

PS

$\mathrm{PsP}_{\mathrm{L}}$

$\mathrm{PsP}_{\mathrm{M}}$

PVBh

Saito 1984

Seyfort Ruegg 1981

Seyfort Ruegg 1991

Seyfort Ruegg 2000

Seyfort Ruegg 2002

Skt
Nyāyamukha.

Claus Oetke, Prasannapadā 19,3-7 and Its Context. WZKS 47 (2003) 109-142.

Peking.

Prajñāpradīpa.

Prajñāpradīpațīkā.

Karin Preisendanz, Studien zu Nyāyasūtra III.1 mit dem Nyāyatattvāloka Vācaspati Miśras II. [Alt- und Neuindische Studien 46]. Institut für Kultur und Geschichte Indiens und Tibets, Universität Hamburg. Stuttgart: Franz Steiner Verlag, 1994.

Pramāṇasamuccaya.

Mūlamadhyamakakārik̄̄s (Mādhyamikasūtras) de Nāgārjuna avec la Prasannapadā Commentaire de Candrakīrti. Ed. de La Vallée Poussin. [Bibliotheca Buddhica 4]. St. Petersburg 1903-1913. Repr. Osnabrück : Biblio Verlag, 1970.

The Prasannapadā, Chapter One. A. MacDonald. Unpublished dissertation. Vienna 2003.

Pramānavārtikabhāshyam or Vārtikālainkārah of Prajñākaragupta. Ed. R. Sānkrityāyana. Patna: Kashi Prasad Jayaswal Research Institute, 1953.

Akira Saito, A Study of the Buddhapālita-Mūlamadhyamakavrtti. Unpublished dissertation, Australian National University, 1984.

David Seyfort Ruegg, The Literature of the Madhyamaka School of Philosophy in India. [A History of Indian Literature, ed. J. Gonda, Vol. VII, fasc. 1]. Wiesbaden: Harrassowitz, 1981.

Id., On pramāna Theory in Tson kha pa's Madhyamaka Philosophy. In: Studies in the Buddhist Epistemological Tradition. Proceedings of the Second International Dharmakīrti Conference. Wien: Verlag der Österreichischen Akademie der Wissenschaften, 1991, p. 281-310.

Id., Three Studies in the History of Indian and Tibetan Madhyamaka Philosophy. [Studies in Indian and Tibetan Madhyamaka Thought]. Part I. [WSTB 50]. Wien: Arbeitskreis für Tibetische und Buddhistische Studien, 2000.

Id., Two Prolegomena to Madhyamaka Philosophy. Candrakīrti's Prasannapadā Madhyamakavrottị on Madhyamakakārikā I.1 and Tson kha pa blo bzań grags pa / rGyal tshab dar ma rin chen's dKa' gnad / gNas brgyad kyi zin bris. [Studies in Indian and Tibetan Madhyamaka Thought]. Part II. [WSTB 54]. Wien: Arbeitskreis für Tibetische und Buddhistische Studien, 2002.

Sanskrit 
Speijer 1988

Stcherbatsky 1927

Stcherbatsky 1989

Tib

Tillemans 1992

Tillemans 2000

Tucci 1929

Tucci 1930

YD

Yonezawa 1999

Yotsuya 1999
J.S. Speijer, Sanskrit Syntax. Leiden 1886. Repr. Delhi: Motilal Banarsidass, 1988.

Th. Stcherbatsky, The Conception of Buddhist Nirvāna. Leningrad: Publishing Office of the Academy of Sciences of the USSR, 1927.

Id., The Conception of Buddhist Nirvāna. Reprint of the second revised and enlarged edition Delhi: Motilal Banarsidass, 1977.

Tibetan

Tom Tillemans, Tsong kha pa et al. on the BhāvavivekaCandrakīrti Debate. In: S. Ihara and Z. Yamaguchi (ed.), Tibetan Studies. Proceedings of the 5th Seminar of the International Association for Tibetan Studies. [Monograph Series of Naritasan Institute for Buddhist Studies: Occasional Papers 2]. Narita 1992, p. 315-326.

Id., Dharmakīrti's Pramānavārttika. An annotated translation of the fourth chapter (parārthānumāna). Wien: Verlag der Österreichischen Akademie der Wissenschaften, 2000. G. Tucci, Buddhist Logic before Dignāga. JRAS (1929) 451-488.

Id., The Nyāyamukha of Dignāga. [Materialien zur Kunde des Buddhismus 15]. Heidelberg 1930.

Yuktidīpik̄̄. The Most Significant Commentary on the Sāmkhyakārikā. Ed. A. Wezler - S. Motegi. Stuttgart: Franz Steiner Verlag, 1998.

Yoshiyasu Yonezawa, *Lakșanațīkā: A Sanskrit Manuscript of an Anonymous Commentary on the Prasannapad $\bar{a}$. JIBS 47,2 (1999) 1024-1022.

Kodo Yotsuya, The Critique of Svatantra Reasoning by Candrakīrti and Tsong-kha-pa. [Tibetan and Indo-Tibetan Studies 8]. Stuttgart: Franz Steiner, 1999. 
